\title{
\#EdTechHub
}

Realising the potential of technology in education

\section{Deploying an e-Learning Environment in Zanzibar: Feasibility assessment}

Caspar Groeneveld, Dr Elia Kibga, Tom Kaye

EdTech Hub, https://edtechhub.org

Technical Guidance No. 1

2020-07-20

DOI: $10.5281 /$ zenodo.3941727

About this document 
For enquiries please email helpdesk@edtechhub.org.

Recommended citation.

Licence.

Creative

Commons

Acknow-

ledgement
Groeneveld, C., Dr. Elia Kibga, E., and Kaye, T. (2020). Deploying an e-Learning Environment in Zanzibar: Feasibility Assessment. (EdTech Hub Technical Guidance 1) DOI: 10.5281/zenodo.3941727E.

Available from: https://docs.edtechhub.org/lib/K7JDL4IL. Available under Creative Commons Attribution 4.0 International, https://creativecommons.org/licenses/by/4.0/.

Creative Commons Attribution 4.0 International https://creativecommons.org/licenses/by/4.0/.

You - dear readers - are free to share (copy and redistribute the material in any medium or format) and adapt (remix, transform, and build upon the material) for any purpose, even commercially. You must give appropriate credit, provide a link to the license, and indicate if changes were made. You may do so in any reasonable manner, but not in any way that suggests the licensor endorses you or your use.

\section{Identifiers. $\quad$ 2405685:K7JDL4IL;10.5281/zenodo.3941727E}

\section{Internal use. g/d/1VYwtRc3SIFiqllffpqNGpHJ7bboRRxgS7KKgZsOjarl/edit\#}

Notes. $\quad$ The EdTech Hub is supported by UK aid from the UK government; however the views expressed are the views of the authors and do not necessarily reflect views of our donors. 
Terms and abbreviations

1. Executive Summary 5

2. Introduction 7

2.1. Overview of the assignment 7

2.2. Principles 7

2.3. Methodology 8

3. The Zanzibar education system 9

3.1. System analysis 9

3.2. Policy environment 17

3.3. Stakeholders 18

3.4. Zanzibar's response to COVID-19 20

3.5. VLE usage scenarios 21

3.6. Summary of situational analysis $\quad 21$

4. Types of Virtual Learning Environments 23

4.1. Types of content organisation 23

4.2. Types of Learning Management System 25

4.3. Virtual Learning Environments: implementation approaches 26

5. Recommendations 29

5.1. Recommendation 1: Focus on quickly building and publishing a content base 29

5.2. Recommendation 2: Clearly define roles and responsibilities 29

5.3. Recommendation 3: Build capacity to execute roles 30

5.4. Recommendation 4: Create an iterative process of piloting and trialling VLEs 30

6. Next steps 31

6.1. Next steps in the short term 31

6.2. Next steps in the medium to long term 35

6.3. Summary of the recommendations and next steps 39

$\begin{array}{ll}\text { 7. References } & 40\end{array}$

8. Annex 1-Overview of existing platforms and content 41

9. Annex $2-$ Usage scenarios 47 


\section{Terms and abbreviations}

\begin{tabular}{|c|c|}
\hline Terms & \\
\hline $\mathrm{CIE}$ & Chief Inspectorate of Education \\
\hline ColCT & College of Information and Communication Technologies \\
\hline DPPR & Department of Policy, Planning and Research \\
\hline DSE & Department of Secondary Education \\
\hline DTE & Department of Teacher Education \\
\hline EMIS & Education Management Information System \\
\hline GPE & Global Partnership for Education \\
\hline IVR & Interactive voice response \\
\hline LMS & Learning Management System \\
\hline MECP-Z & Madrassa Early Childhood Programme Zanzibar \\
\hline NA & Needs Assessment \\
\hline OCGS & Office of Chief Government Statisticians \\
\hline OER & Open Educational Resources \\
\hline PORALGSD & $\begin{array}{l}\text { President's Office Regional Administration Local Government and } \\
\text { Special Department }\end{array}$ \\
\hline PO-RALG & President's Office Regional Administration and Local Government \\
\hline SIDA & Swedish International Development Agency \\
\hline SUZA & State University of Zanzibar \\
\hline UNICEF & United Nations Children's Fund \\
\hline VLE & Virtual Learning Environment \\
\hline WEMA & Wizara ya Elimu na Mafunzo ya Amali \\
\hline ZANTEL & Zanzibar Telecommunication \\
\hline ZBC & Zanzibar Broadcasting Company \\
\hline ZIE & Zanzibar Institute of Education \\
\hline ZMRC & Zanzibar Madrasa Resource Centre \\
\hline
\end{tabular}




\section{Executive Summary}

In April 2020, Zanzibar's Ministry of Education and Vocational Training and the World Bank engaged the EdTech Hub to explore whether and how a Virtual Learning Environment (VLE) could be deployed in Zanzibar.

As requested, this report provides a practical and actionable analysis of the factors relevant for deploying an e-learning platform in Zanzibar. The report analyses the education system, human resource capacity, existing infrastructure, policy support and the stakeholder environment. It concludes with recommendations and next steps.

The Hub team worked closely with a technical team nominated by Abdulla Mzee, Deputy Permanent Secretary, with close assistance from Khalid Wazir, Director of Policy, Planning and Research. The team comprised the following personnel:

- Khalid Wazir, Director of the Department of Policy, Planning and Research

- Othman S. Othman, head of EMIS

- Omar S. Ali, Director of ICT

- Omar Ali Hassan, Zanzibar Institute of Education

- Othman Omar Othman, Department of Policy, Planning and Research

- Haroub Hamad, Department of Secondary Education

- Khamis M. Abdi, Department of Teacher Education

- Abdillahi Mahzumi, ICT

- Dr. Mary A. Mtumwa, Department of Policy, Planning and Research

- Amiri Mdoe, Pre-primary and primary education coordinator (PORALGSD)

- Zaharia M. Alawy, Pre-primary and primary education coordinator (PORALGSD)

The technical team participated in a series of virtual meetings and data collection workshops facilitated by the Hub between 15 May and 23 June. Senior MoEVT staff also participated as relevant. Based on these workshops the Hub team developed a set of draft findings and recommendations that were presented to the ministry. This report has been finalised taking into consideration feedback received during this meeting.

The education system analysis showed that there are over 1,000 schools in Zanzibar serving approximately 600,000 children. While access to education has improved in the last decades, there is a shortage of qualified teachers in pre-primary and primary schools, and of qualified teachers for science subjects in secondary schools.

Data on ICT Infrastructure shows most schools have electricity, although the quality of electrification remains unclear. There is an average of one computer per school for teacher use and one for student use. There is also an average of one television per school. However, the computers are not distributed evenly, with more than half of schools having no computers, and there is no data on the age or specifications of the computers. Very few schools, if any, appear to have an internet connection, in spite of a national backbone being in place. Teachers have low capacity in using ICT or integrating technology in teaching.

The region has a policy environment that is conducive to integrating technology into education. Policies support the development of digital content, the provision of reliable 
and affordable access to ICT and internet for educational institutions, and curriculum reorganisation to correspond with ICT-enhanced teaching and learning. In spite of the policies, practical targets and implementation plans are not always in place.

Deploying a VLE in Zanzibar will require the support of three types of stakeholders: government, users and partners. While many government agencies are relevant for the implementation of a VLE, their roles seem to overlap at times. Capacity needs to be strengthened among both government and user stakeholders to effectively implement a VLE. Partner stakeholders are non-governmental players such as NGOs or international donors, and may play a role in funding, rolling-out, implementing or facilitating a VLE in Zanzibar. As with government agencies, identified partners sometimes had overlapping roles and expectations.

The information, discussions and findings have led to four recommendations:

1. Focus on quickly building and publishing a content base: Content selection, curation, adaptation and development can begin immediately. Ideally, this content should be sourced from existing content repositories that are suitable for the region and require the least modification. This content base should be well structured and organised to fit different distribution models, including existing channels. The first steps for trialling a VLE can be taken in parallel with this work.

2. Clearly define roles and responsibilities: $A$ lack of clear role articulation and collaboration may lead to parallel actors executing the same tasks, creating inefficiencies and confusion. Identifying roles and assigning ownership and responsibilities is a prerequisite to making VLE implementation a success. A full mapping of all actors, including their roles and responsibilities, should be performed to ensure that all potential roles and responsibilities are identified and documented.

3. Build capacity to execute roles: Actors involved in implementing a VLE should be supported to build the capacity they require to execute their roles. This may include teachers, content designers, programmers and MoEVT officials, among others.

4. Create an iterative process of piloting and trialling VLEs: Zanzibar's context is unique. It is important that any VLE is adequately tested and adapted to ensure both effectiveness and sustainability. The MoEVT should pursue an iterative process of piloting and rolling out a VLE to ensure that any solution aligns with the local context. This process should trial a number of different platforms, as well as corresponding approaches to teacher professional development, adapting those that show promise and dismissing those that do not. After multiple small-scale trials, the most effective and sustainable approach should be scaled up.

Based on these recommendations, the report concludes with a set of practical steps that can be taken in both the short and medium to long term that will allow Zanzibar to begin moving towards deploying a virtual learning environment. 


\section{Introduction}

\subsection{Overview of the assignment}

The Zanzibar MoEVT and the World Bank approached the Hub in April 2020 to explore the feasibility of implementing a VLE. The MoEVT, the World Bank and the Hub agreed that the Hub would work with the MoEVT to develop:

1. a practical and actionable report analysing key factors to be considered in deploying an e-learning platform in Zanzibar;

2. a report documenting the process of sourcing appropriate content, aligning this content with the curriculum and populating the e-learning system accordingly;

3. an implementation plan to guide the deployment of the e-learning system.

This document addresses part one of the request.

The report was made possible through the strong collaboration between the MoEVT and the Hub. The teams have worked closely together, with the MoEVT providing data and insights into the Zanzibar context. The Hub has integrated the insights provided by the MoEVT with their knowledge of international effective practices in deploying VLEs.

The report has been made actionable by identifying and addressing key questions related to the deployment of a VLE in Zanzibar including the following:

- What are the key factors that are relevant for deploying a VLE in Zanzibar?

- Who are the potential users of a VLE and how will they engage with the system?

- What opportunities and barriers may facilitate or impede the adoption of a VLE?

- What are the practical implications of these opportunities and barriers?

- How can these barriers be overcome, and the opportunities leveraged?

- What sort of VLEs are available?

- How could the proposed VLE be implemented?

The report is structured around the following sections as follows:

- This introduction, which provides the background and guiding principles for the engagement as well as a short overview of the methodology applied in creating this report.

- An analysis of the Zanzibar education system with a particular focus on elements relevant to deploying a VLE. This includes the status of ICT infrastructure, and a summary of the stakeholders who will play a role in using or implementing a VLE.

- A discussion of the types of VLEs and content organisation, and their applicability to the Zanzibar ecosystem.

- A conclusion containing four recommendations to be considered as Zanzibar explores implementing a VLE.

- A final section outlining next steps for both the short- and long-term.

\subsection{Principles}

The Hub takes a problem-driven, rather than a tech-driven, approach. This means it focuses primarily on questions such as: 
- What is the education challenge that needs to be solved?

- What are the potential solutions?

- Is there an appropriate and effective application of technology in the solution?

- How can funding be used to sustainably strengthen education systems?

- How can existing ICT infrastructure be best leveraged?

- How can different technologies be integrated to reach the most children?

Education comes first, and technology can be a tool to address an education problem.

In this collaboration with Zanzibar's MoEVT, this has meant that the Hub team sought to understand the purpose of the proposed VLE. Based on discussions and user scenarios, we identified two main education challenges that a VLE may help to resolve. In the short term, students cannot go to school during the COVID-19 crisis, but need access to educational content. There is content, but no flexible and versatile platform to disseminate content to all students. In the long term, a mechanism to provide students with access to quality, curriculum-aligned content in school or remotely, is required.

\subsection{Methodology}

The World Bank, the Hub and the MoEVT had a kick-off meeting on 15 May 2020, which established a common understanding of the project, scope, expected deliverables and timeline for each deliverable. Following the meeting the MoEVT formed a group of staff to support the Hub team with data collection. The Hub relied heavily on the technical team to provide contextual information and to collect, collate and share data.

The Hub team prepared various tools and templates for collecting data on:

- the enrollment of students by grades;

- teachers by grade levels;

- the impact of COVID-19 on education;

- network and electricity coverage;

- available platforms;

- policies which support a VLE;

- stakeholders of VLE implementation;

- needs assessment for the capacity building purposes.

The MoEVT team received training on the use of the data-collection tools on 28 May 2020, followed by another workshop on 5 June 2020, which concluded the data collection task. A final workshop, to develop user scenarios and expectations about how a VLE would be used in Zanzibar, took place on 11 June 2020. Finally, a draft of the recommendations was presented to the MoEVT and World Bank on 23 June 2020. This document was finalised based on comments and recommendations from that meeting. 


\section{The Zanzibar education system}

This section provides an analysis of the Zanzibar education system. It examines key education system data, reviews the policy environment, outlines key stakeholders, describes the impact of the COVID-19 pandemic and summarises proposed VLE usage scenarios. The section ends with a summary of the key findings as they relate to deploying a VLE in Zanzibar.

The analysis focuses on assessing the feasibility of deploying a VLE in Zanzibar. We have only included information relevant to this purpose. This means that we have not included some data that might otherwise be included in an education sector analysis. For example, we have included the number of schools, but not the number of classrooms. We have also included data specifically relevant to deploying a VLE. For example, we include access to computers and an analysis of the policy environment as it relates to deploying a VLE. The majority of the data in this section was provided by the MoEVT team. Where data was obtained from other sources these have been cited. The section.

\subsection{System analysis}

This system analysis provides insights into the size and scope of the Zanzibar education system. The elements reviewed include the system structure, enrollments, teacher availability, the urban / rural divide, ICT infrastructure and student learning outcomes.

\subsubsection{System structure, school, students and teachers}

In Zanzibar, the first 12 years of education are compulsory and free. These 12 years traverse 2 years of pre-primary, 6 years of primary (Standards I to VI) and 4 years of secondary education (Forms 1 to 4). Beyond basic education, Forms 5 and 6 constitute Advanced Level (A-level).

Table 1. Structure of Zanzibar education system

\begin{tabular}{|c|c|c|c|}
\hline Level & Age & Grade name & Language of instruction \\
\hline \multirow[t]{2}{*}{ Pre-primary } & 4 & & \multirow{6}{*}{ Swahili } \\
\hline & 5 & & \\
\hline \multirow[t]{6}{*}{ Primary } & 6 & Standard I & \\
\hline & 7 & Standard II & \\
\hline & 8 & Standard III & \\
\hline & 9 & Standard IV & \\
\hline & 10 & Standard V & \multirow{2}{*}{$\begin{array}{l}\text { English is the main language of } \\
\text { instruction. Swahili is used as a } \\
\text { language of instruction in Swahili }\end{array}$} \\
\hline & 11 & Standard VI & \\
\hline
\end{tabular}




\begin{tabular}{|c|c|c|c|}
\hline & & & $\begin{array}{l}\text { language classes. Islamic and } \\
\text { Arabic subjects are taught in } \\
\text { Arabic. }\end{array}$ \\
\hline \multirow[t]{6}{*}{ Secondary } & 12 & Form 1 & \multirow{6}{*}{ English } \\
\hline & 13 & Form 2 & \\
\hline & 14 & Form 3 & \\
\hline & 15 & Form 4 & \\
\hline & 16 & Form 5 & \\
\hline & 17 & Form 6 & \\
\hline
\end{tabular}

\subsubsection{Schools, students, teachers and leadership}

Zanzibar is home to just over 1,000 pre-primary, primary and secondary schools. Approximately half of these are private schools. Private schools tend to be smaller than public schools and are more prevalent in earlier years as is shown in Table 2.

Table 2. Schools and students by school type (Othman, 2020b).

\begin{tabular}{|l|r|r|r|r|}
\hline & \multicolumn{1}{|l|}{ Total } & Public & Private & \multicolumn{2}{l|}{$\begin{array}{l}\text { Private } \\
\text { schools }\end{array}$} \\
\hline Pre-primary & 363 & 35 & 328 & $90 \%$ \\
\hline Primary & 431 & 293 & 138 & $32 \%$ \\
\hline Secondary and Basic & 295 & 213 & 82 & $28 \%$ \\
\hline All schools & $\mathbf{1 , 0 8 9}$ & $\mathbf{5 4 1}$ & $\mathbf{5 4 8}$ & $\mathbf{5 0 \%}$ \\
\hline
\end{tabular}

Of Zanzibar's population of circa 1.5 million people, approximately 600,000 are of school-going age. Table 3 shows the population of boys and girls of school-going age, the number of actual enrollments by grade level, the gross enrollment rates for the different levels of education, and, where available, dropout rates. 
Table 3. Population of school-aged children and gross enrollment rate by education level (Education Statistical Abstract (Unpublished), 2019; Othman, 2020b). ${ }^{1}$

\begin{tabular}{|l|r|r|r|r|r|r|r|r|}
\hline & \multicolumn{4}{|c|}{ Population (2020) } & Enrolled & \multicolumn{2}{|c|}{$\begin{array}{c}\text { Gross enrollment } \\
\text { rate (2020) }\end{array}$} & $\begin{array}{c}\text { Dropout } \\
\text { (2018) }\end{array}$ \\
\hline & \multicolumn{1}{|c|}{ Boys } & \multicolumn{1}{|c|}{ Girls } & Total & Total & Boys & Girls & Total & Total \\
\hline Pre-primary & 53,908 & 53,174 & 107,082 & 92,097 & $84 \%$ & $88 \%$ & $86 \%$ & \\
\hline Primary & 130,305 & 129,164 & 259,469 & 313,097 & $122 \%$ & $120 \%$ & $121 \%$ & $6 \%$ \\
\hline Forms 1-4 & 78,373 & 78,229 & 156,602 & 124,493 & $72 \%$ & $87 \%$ & $80 \%$ & $39 \%$ \\
\hline Forms 5-6 & 32,876 & 33,665 & 66,541 & 5,679 & $9 \%$ & $9 \%$ & $9 \%$ & \\
\hline All students & $\mathbf{2 9 5 , 4 6 2}$ & $\mathbf{2 9 4 , 2 3 2}$ & $\mathbf{5 8 9 , 6 9 4}$ & $\mathbf{5 3 5 , 3 6 6}$ & $\mathbf{8 9} \%$ & $\mathbf{9 3 \%}$ & $\mathbf{9 1 \%}$ & \\
\hline
\end{tabular}

The high levels of enrollment has meant that many schools in Zanzibar have adopted double- or even triple-shift approaches to meeting student demand. A single-shift school teaches one cohort, while double shifts occur when some students are taught in the morning while others are scheduled in the afternoon session. Approximately 14 per cent of Zanzibar schools deploy a double-shift approach in at least some of their classrooms (Ministry of Education and Vocational Training \& UNICEF, 2018). Although double shifting allows more students to access schools, it can negatively impact learning quality. Negative impacts may include, but are not limited to, reducing the amount of instructional hours that a class receives, and making it more difficult for teachers to gain the same level of insight and provide the same level of attention to each child. This can lead to lower levels of learning and higher levels of dropout.

While enrollment in primary school is high, retention is difficult. Nearly 40 per cent of students who enrol do not complete secondary education. In particular, high-stakes exams are a barrier to student retention. These exams occur at three points:

1. An exit exam from primary (Standard VI exam).

2. An exit exam from lower secondary (Form 2 exam).

3. An exit exam from upper secondary (Form 4 exam).

The drop in gross enrollment between primary (120.7 per cent) and secondary (79.5 per cent) highlights the barrier posed by high-stakes exams. Figure 1 shows dropout rates per year and cumulative dropout rates.

\footnotetext{
${ }^{1}$ The gross enrollment rate is the total number of students enrolled in each school level divided by the total number of students in that age group. A rate higher than 100 per cent occurs for reasons including late enrollment or not transitioning to the next grade.
} 
Figure 1. Dropout rates per year and cumulative dropout rate in primary and secondary schools in 2018 (Education Statistical Abstract (Unpublished), 2019).

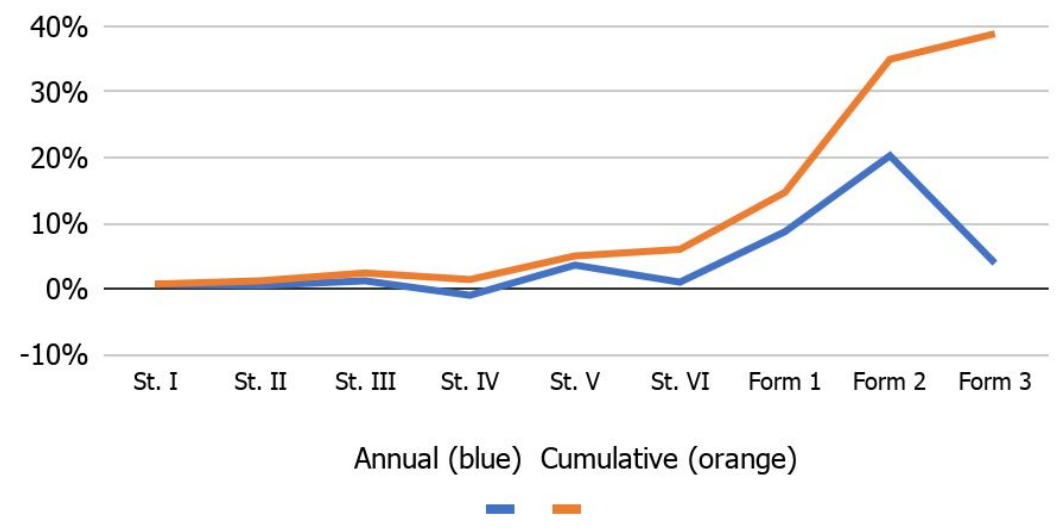

In 2018 there were close to 6,000 students with special needs in schools, constituting two per cent of the student population. Disabilities include impaired hearing, impaired sight, muteness, mental disabilities and others (Table 4). There is no data available on the number of students with disabilities who are not attending school.

Table 4. Students with disabilities by education level in 2018 (Othman, 2020a).

\begin{tabular}{|c|c|c|c|c|}
\hline Disability type & Pre-primary & Primary & Secondary & Total \\
\hline Visually impaired & 13 & 209 & 187 & 409 \\
\hline Physical disability & 59 & 564 & 137 & 760 \\
\hline Deaf & 59 & 776 & 130 & 965 \\
\hline Speech disability & 168 & 375 & 83 & 626 \\
\hline Mental health disability & 41 & 346 & 32 & 419 \\
\hline Mixed & 24 & 162 & 37 & 223 \\
\hline $\begin{array}{l}\text { Partially visually } \\
\text { impaired }\end{array}$ & 59 & 1,146 & 1,018 & 2,223 \\
\hline Albino & 8 & 37 & 8 & 53 \\
\hline Other & 53 & 191 & 75 & 319 \\
\hline Total & 484 & 3,806 & 1,707 & 5,997 \\
\hline
\end{tabular}

When viewing Zanzibar's education system holistically, teacher provision appears adequate. There is an average of 29 students per teacher across pre-primary, primary and secondary public and private schools. However, what this average conceals is a shortage of teachers at lower levels of education. In public primary schools the student-teacher ratio is $43: 1$. This contrasts with an average of $22: 1$ in public 
secondary schools. In private schools there are about half as many students per teacher as in public schools (Table 5). Additionally, while the student-teacher ratio in Zanzibar is in line with international standards, these general figures mask other disparities. Urban schools typically have many more students per teacher, whereas others in remote areas have far fewer students per teacher. Additionally, in some areas where there are adequate teachers there are few available classrooms, with classrooms still being overcrowded due to a lack of infrastructure within the schools (Othman, 2020a).

Table 5. Students and teachers in public and private schools (Othman, 2020b).

\begin{tabular}{|c|c|c|c|c|c|c|}
\hline & \multicolumn{2}{|c|}{$\begin{array}{c}\text { Number of students } \\
\text { enrolled }\end{array}$} & \multicolumn{2}{|c|}{ Number of teachers } & \multicolumn{2}{|c|}{ Student-teacher ratio } \\
\hline & $\begin{array}{l}\text { Public } \\
\text { schools }\end{array}$ & $\begin{array}{l}\text { Private } \\
\text { schools }\end{array}$ & $\begin{array}{l}\text { Public } \\
\text { schools }\end{array}$ & $\begin{array}{l}\text { Private } \\
\text { schools }\end{array}$ & $\begin{array}{l}\text { Public } \\
\text { schools }\end{array}$ & $\begin{array}{l}\text { Private } \\
\text { schools }\end{array}$ \\
\hline Pre-primary & 40,673 & 51,425 & 955 & 2,022 & 43 & 25 \\
\hline Primary & 275,580 & 37,517 & 6,816 & 2,151 & 40 & 17 \\
\hline Secondary & 116,486 & 13,686 & 5,312 & 1,391 & 22 & 10 \\
\hline $\begin{array}{l}\text { Total / } \\
\text { Average } \\
\text { ratio }\end{array}$ & 432,739 & 102,628 & 13,083 & 5,564 & 33 & 18 \\
\hline
\end{tabular}

Additionally, teachers are frequently unqualified. In 2018, only 51 per cent of primary teachers were qualified (Education Statistical Abstract (Unpublished), 2019). There is no data on the quality, training or qualifications of teachers in private schools. Additionally, most education leadership positions (e.g., School Inspector and District Education Officer) only require the employee to be a teacher to qualify for such a leadership position. However, the abundance of unqualified teachers can result in unqualified teachers being employed as education leaders.

\subsubsection{Urban and semi-urban schools}

Zanzibar does not have distinct definitions of urban and rural areas. However, of the 11 districts in the region, 6 are considered urban and 5 are semi-urban. While approximately half of the districts are semi-urban, these districts contain only approximately one-third of the schools and students, and one fifth of the teachers (Table 6). A comparison of the student-teacher ratio in semi-urban and urban regions (Table 7) shows that there is no great disparity between the regions, even though semi-urban schools have more students per teacher than urban schools. 
Table 6. Distribution of schools and students in urban and semi-urban areas (Othman, 2020b).

\begin{tabular}{|l|r|r|r|r|r|r|}
\hline & \multicolumn{3}{|c|}{ Urban areas } & \multicolumn{3}{c|}{ Semi-urban areas } \\
\hline & Schools & Students & Teachers & Schools & Students & Teachers \\
\hline Pre-primary & 269 & 74,033 & 2,145 & 94 & 33,049 & 832 \\
\hline Primary & 280 & 176,745 & 6,237 & 151 & 82,724 & 2,730 \\
\hline Secondary & 197 & 112,828 & 5,019 & 98 & 48,644 & 1,684 \\
\hline Total & $\mathbf{7 4 6}$ & $\mathbf{3 6 3 , 6 0 6}$ & $\mathbf{1 3 , 4 0 1}$ & $\mathbf{3 4 3}$ & $\mathbf{1 6 4 , 4 1 7}$ & $\mathbf{5 , 2 4 6}$ \\
\hline
\end{tabular}

Table 7. Student-teacher ratio in public and private schools (Othman, 2020b).

\begin{tabular}{|l|r|l|l|r|}
\hline Children per teacher & $\begin{array}{l}\text { Urban } \\
\text { child-teacher }\end{array}$ & $\begin{array}{l}\text { Semi-urban } \\
\text { child-teacher }\end{array}$ & $\begin{array}{l}\text { Urban } \\
\text { child-school }\end{array}$ & $\begin{array}{l}\text { Semi-urban } \\
\text { child-school }\end{array}$ \\
\hline Pre-primary & 35 & 40 & 275 & 352 \\
\hline Primary & 28 & 30 & 631 & 548 \\
\hline Secondary (Forms 1-6) & 22 & 29 & 573 & 496 \\
\hline
\end{tabular}

\subsubsection{ICT Infrastructure}

Most public schools and around two-thirds of private schools in Zanzibar have electricity (Table 8). There is, however, no information on the consistency of supply and the frequency or duration of power outages.

Table 8. Electrification per school type (Othman, 2019).

\begin{tabular}{|l|l|l|}
\hline & Public & Private \\
\hline Primary & $83.2 \%$ & $62.7 \%$ \\
\hline Secondary & $91.5 \%$ & $69.1 \%$ \\
\hline
\end{tabular}

The number of computers and televisions in schools is low. The 1,089 public and private schools combined have between 2,000 and 2,500 computers and around 1,000 televisions (Othman, 2020a). However, around 40 per cent of these computers are intended for teachers and not for students. Moreover, the distribution of these computers is not equal. Around 65 per cent of public schools have no computer at all, while one in 25 schools have more than 21 computers. Figure 2 shows the distribution of computers in public and private schools in the region. 
Figure 2. Number of computers in public and private schools in Zanzibar (Department of Planning, Policy and Research, 2019).



While data on numbers of computers exists, it is unclear how old the computers are, whether they are operational, or whether they can support current software systems.

Despite some access to devices, there appears to be little internet connectivity in schools and offices. A sample needs assessment was conducted, which collected data on internet connectivity. It identified that only half of the offices in Pemba and Unguja are connected to the internet, although a national backbone is in place (Mahzumi, 2020). There is no data on the number or percentage of schools connected to the internet.

Even in schools equipped with computers and televisions teacher capacity to effectively integrate devices into teaching and learning processes is low. The aforementioned needs assessment of teachers highlighted that only 25 per cent of teachers are comfortable using technology in teaching. The Zanzibar Education Policy concludes that even where technology is available it is not used to enhance teaching and learning as teachers do not have the relevant skills to do so (Zanzibar Education Policy, 2006).

\subsubsection{Student performance}

Student performance is low and falling. Early Grade Reading and Mathematics Assessments (EGRA and EGMA) were conducted in 2016 with Standard II students (i.e., seven-to-eight-year-olds). The results, provided in Figure 3, indicate that early grade literacy and numeracy are well below the Tanzanian benchmarks. Of standard II students, four per cent meet the benchmarks for "oral reading fluency", and five per cent for "reading comprehension". Numeracy fares worse, with zero per cent managing the benchmark for "addition and subtraction" and two per cent for "missing number". 
Figure 3: 2016 EGRA and EGMA Results for Zanzibar (RTI International, 2016).

100

75

75

50

25

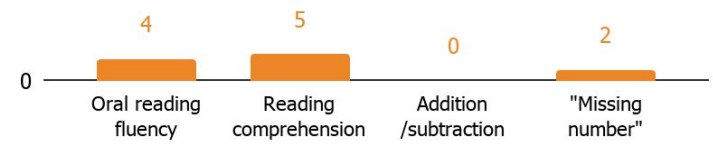

\% Meeting benchmarks

Results data from Zanzibar's Form 2 examinations also indicate that learning levels are low and that performance is decreasing. Average Form 2 exam scores dropped from 30.5 per cent to 25.9 per cent between 2016-2018. Performance in private schools is slightly higher, with an average Form 2 exam score of 35.8 per cent in 2018. In particular, languages fare better in private schools, with exam scores for Swahili of 47.1 per cent, and of 41.3 per cent for English, compared with 33 per cent and 23.7 per cent respectively in government schools. Figures 4 and $\underline{5}$ outline the diminishing results in Form 2 assessments between 2016 and 2018.

Figure 4. Form 2 exam scores (\%) for the years 2016-2018 (Education Statistical Abstract (Unpublished), 2019).

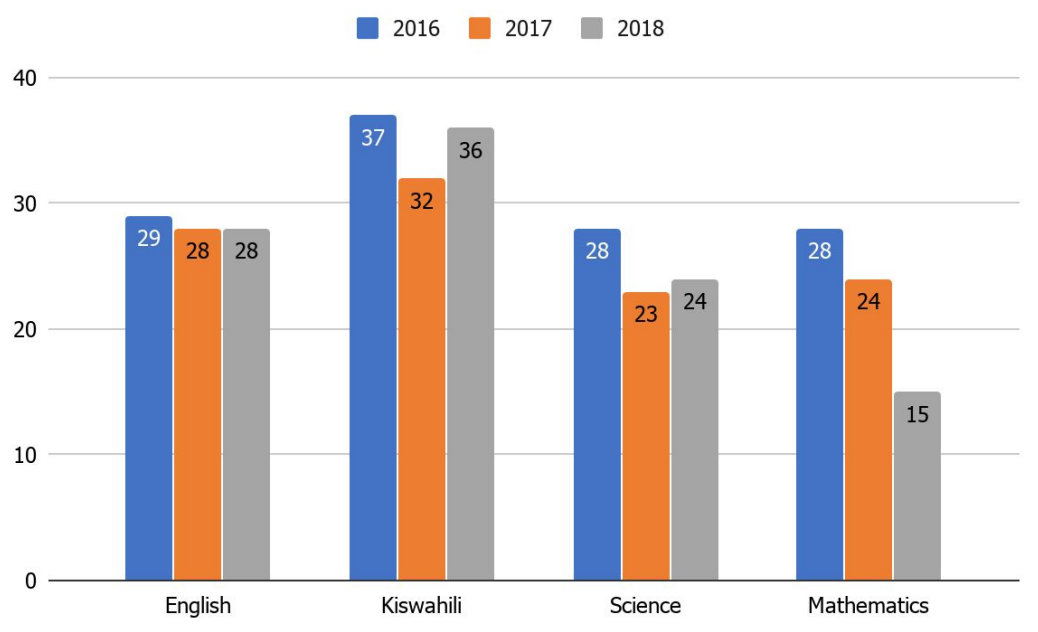


Figure 5. Form 2 exam scores (\%) in 2018 for public and private schools (Education Statistical Abstract (Unpublished), 2019).

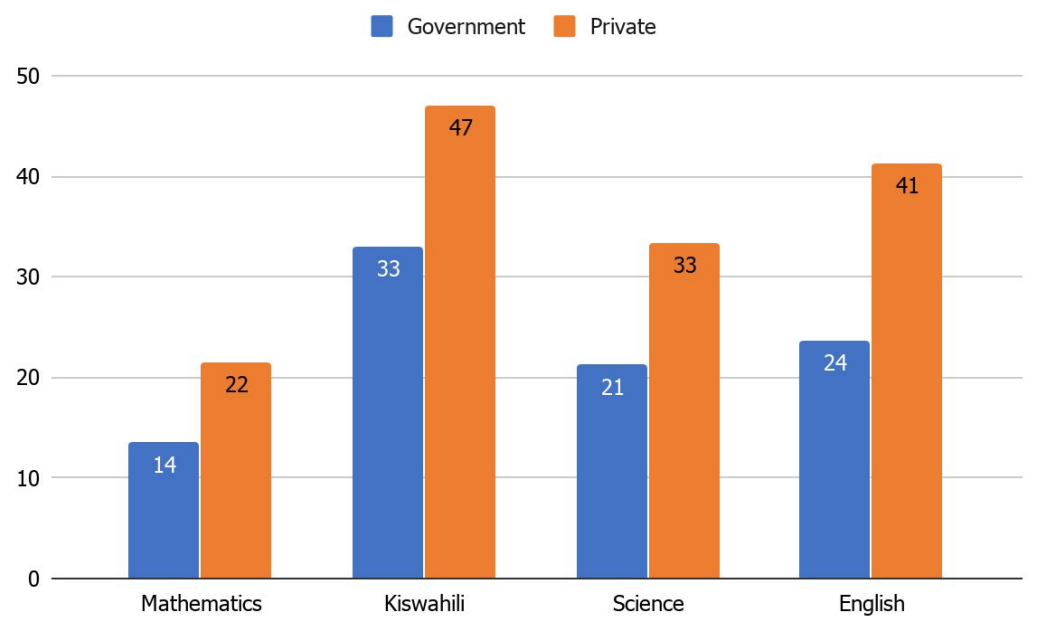

\subsection{Policy environment}

The 2013 Zanzibar ICT Policy outlines several strategies for the deployment and use of ICT in Zanzibar's educational system (Zanzibar ICT Policy, 2013). This includes:

- Develop local e-learning resources for primary, secondary and tertiary education.

- Provide reliable and affordable access to ICT resources for all educational and research institutions.

- Establish e-learning and virtual learning centres in higher education and professional training institutions.

The provisional 2019 Zanzibar Education and Training Policy expands this further:

- Ensure that all schools, teacher training colleges, teacher centres, universities and other formal and informal public educational institutions have access to a full array of digital learning resources via reliable internet access and intranet.

- Reorganise existing curricula so that they correspond with ICT enhanced teaching and learning strategies.

- Ensure the availability of enrichment software and applications to complement and supplement traditional educational materials to formal and informal, private and public educational institutions.

- Mobilise higher learning institutions to support the use of ICT for teaching higher-order thinking skills and 21st-century knowledge and skills, at all levels.

- Ensure the establishment of e-Libraries to increase e-resource learning centres in teacher-training colleges, teacher centres and other formal and informal public educational institutions.

While the policies do not explicitly reference implementing a VLE for basic education, they do have the goal of developing virtual learning centres in higher education institutions. Additionally, the policies highlight the need to develop e-learning resources 
and have virtual materials to supplement educational materials for formal and informal education. Both of these aims require a VLE to deliver materials.

\subsection{Stakeholders}

Deploying a VLE in Zanzibar will require the support of various stakeholders. Below, we categorise stakeholders in three groups: government, users and partners. Tables 9-11 highlight key actors and, based on inputs from the MoEVT technical team, identify roles and responsibilities assigned to each actor.

\subsubsection{Government Stakeholders}

The MoEVT's departments and institutions will be involved in any VLE implementation in various ways. These are outlined in Table 9.

Table 9. Roles of government agencies in the implementation of a VLE.

\begin{tabular}{|c|c|}
\hline $\begin{array}{l}\text { Government } \\
\text { agency }\end{array}$ & Role \\
\hline $\begin{array}{l}\text { MoEVT Department } \\
\text { of Policy, Planning } \\
\text { and Research } \\
\text { (DPPR) }\end{array}$ & $\begin{array}{l}\text { - Coordinate all three categories of stakeholders. } \\
\text { - Ensure monitoring and evaluation tools are prepared on } \\
\text { time and used to assess VLE implementation in Zanzibar. } \\
\text { - Develop annual monitoring reports for VLE implementation. } \\
\text { - Conduct advocacy with development partners to support a } \\
\text { - VLE. }\end{array}$ \\
\hline $\begin{array}{l}\text { MoEVT ICT } \\
\text { Department }\end{array}$ & $\begin{array}{l}\text { - Ensure connectivity in institutions and TV White Space } \\
\text { - } \text { Connectivity where a VLE is to be used. } \\
\text { curriculum. } \\
\text { - Conduct a stakeholder capacity assessment. } \\
\text { - Design and develop a capacity-building approach. } \\
\text { - Organise and supervise the development of the VLE } \\
\text { - } \text { according to use requirement specifications. } \\
\text { - } \quad \text { Mobilisation of the VLE to stakeholders. }\end{array}$ \\
\hline $\begin{array}{l}\text { MoEVT Department } \\
\text { of Secondary } \\
\text { Education (DSE) }\end{array}$ & $\begin{array}{l}\text { - Create awareness of the VLE among teachers and students. } \\
\text { - } \quad \text { Cupport teachers to integrate technology into teaching. } \\
\text { - } \text { repordinate stakeholders to ensure monitoring and } \\
\text { - Ensure students are trained to effectively use the VLE. }\end{array}$ \\
\hline $\begin{array}{l}\text { MoEVT Department } \\
\text { of Teacher } \\
\text { Education (DTE) }\end{array}$ & $\begin{array}{l}\text { - Collaborate with the ICT department to develop training for } \\
\text { teachers to integrate the VLE into pedagogical approaches. } \\
\text { - Deliver pre- and in-service training to prepare teachers to } \\
\text { effectively integrate the VLE into pedagogical approaches. }\end{array}$ \\
\hline $\begin{array}{l}\text { Zanzibar Institute } \\
\text { of Education (ZIE) }\end{array}$ & $\begin{array}{l}\text { - Control the quality of curated, adapted or created content. } \\
\text { - Update the national curriculum to integrate the use of a VLE. }\end{array}$ \\
\hline
\end{tabular}




\begin{tabular}{|c|c|}
\hline & $\begin{array}{l}\text { Provide expertise on the development of e-content and } \\
\text { training in e-content design and development. }\end{array}$ \\
\hline $\begin{array}{l}\text { State University of } \\
\text { Zanzibar (SUZA) }\end{array}$ & $\begin{array}{l}\text { Provide expertise on the development of e-content and } \\
\text { training in e-content design and development. }\end{array}$ \\
\hline $\begin{array}{l}\text { Chief Inspectorate } \\
\text { of Education (CIE) }\end{array}$ & $\begin{array}{l}\text { - Establish a mechanism to monitor VLE use in the classroom. } \\
\text { - Deliver an annual report assessing VLE implementation. }\end{array}$ \\
\hline $\begin{array}{l}\text { President's Office } \\
\text { Regions } \\
\text { Administration Local } \\
\text { Government } \\
\text { (PO-RALG) }\end{array}$ & $\begin{array}{l}\text { - Raise funds for additional infrastructure. } \\
\text { - Monitor teachers' and institutional needs. } \\
\text { - Liaise with the Zanzibar Broadcasting Commission and } \\
\text { Zantel. }\end{array}$ \\
\hline $\begin{array}{l}\text { Zanzibar } \\
\text { Broadcasting } \\
\text { Corporation }\end{array}$ & - Broadcast educational content. \\
\hline
\end{tabular}

\subsubsection{User stakeholders}

User stakeholders are those who are expected to actively be involved in the use of a VLE in Zanzibar. This includes teachers, students, parents, subject advisors, assistant directors, district education officers (DEOs), principals and school management. The user stakeholders and their roles are described in Table 10.

Table 10. Roles of user stakeholders in the implementation of a VLE.

\begin{tabular}{|c|c|}
\hline Users & Role \\
\hline Students & $\begin{array}{l}\text { - Use the VLE in school or at home. } \\
\text { - Create a community of learners. }\end{array}$ \\
\hline Teachers & $\begin{array}{l}\text { - Deliver lessons through VLE. } \\
\text { - Use sound pedagogy with a VLE. } \\
\text { - Assess learning outcomes. } \\
\text { - involve parents. }\end{array}$ \\
\hline Parents & $\begin{array}{l}\text { - Support children. } \\
\text { - Follow up on learning. } \\
\text { - Make devices in the house available for learning. }\end{array}$ \\
\hline Subject advisors & $\begin{array}{l}\text { - Prepare and support teachers. } \\
\text { - Ensure content matches the curriculum and class. } \\
\text { - Assess teachers' performance on the use of the VLE. }\end{array}$ \\
\hline Assistant directors & $\begin{array}{l}\text { - Create awareness and support among parents and the } \\
\text { community. }\end{array}$ \\
\hline
\end{tabular}




\begin{tabular}{|l|l|}
\hline & $\bullet \quad$ Monitor use of the VLE. \\
\hline $\begin{array}{l}\text { Principals and } \\
\text { school } \\
\text { management }\end{array}$ & - Supervise teachers. \\
& - Manage a VLE at school level. \\
\hline
\end{tabular}

\subsubsection{Partner stakeholders}

Several stakeholders outside of government and users are expected to play a role in implementing a VLE in Zanzibar. This includes both service providers and funders. Table 11 provides an overview of possible partner stakeholders. The DPPR will play a key role in coordinating these partners.

Table 11. Roles of partner stakeholders in the implementation of a VLE.

\begin{tabular}{|l|l|}
\hline Partner & Role \\
\hline ZANTEL (Zanzibar Telecom) & Support school connectivity \\
\hline Zanzibar Madrasa Resource Centre & Support school connectivity \\
\hline UNICEF & Funding and technical support \\
\hline SIDA & Funding and technical advice \\
\hline World Bank & Funding and technical support \\
\hline Global Partnership for Education (GPE) & Funding \\
\hline
\end{tabular}

\subsection{Zanzibar's response to COVID-19}

The first cases of COVID-19 in Zanzibar were detected on 17 March 2020. The government responded by closing many services including schools, colleges and hotels. Meetings and seminars were suspended and social gatherings restricted.

As a response to closing schools, colleges and universities, Zanzibar established a COVID-19 Education Response Plan. This plan, written in collaboration with UNICEF, SIDA, MECP-Z, Milele Foundation and MEDIA, will operate for 18 months and aims to ensure equitable access to quality education. The plan addresses the following areas:

- access to learning;

- protection and wellbeing;

- enabling environments for teachers and students;

- learning assessment;

- community engagement;

- gender equity;

- monitoring and evaluation. 
The strategy outlines how several modalities will be used to deliver content including the internet (e.g., YouTube), TV, radio, mobile telephones and social media. While Zanzibar has some existing content that it can reuse via the above modalities, the lack of a platform to disseminate content in Zanzibar is driving Zanzibar's desire to roll out a VLE.

\subsection{VLE usage scenarios}

As part of the identification of options, expectations, needs and barriers to implementing a VLE, usage scenarios were developed by MoEVT team members. These scenarios (see Annex 2) are insightful. In each scenario, usage fails and the reasons for failure are narrated. These scenarios allow us to identify and categorise barriers in implementing a VLE in Zanzibar. Potential obstacles could be categorised as problems with:

- capacity of all stakeholders, such as students, teachers and parents;

- the school situation, such as overcrowded classes;

- computer infrastructure, such as absent or failing computers;

- connectivity, such as lacking or unreliable internet;

- content, for example too fast, in the wrong language or of a wrong level.

A full analysis of the barriers identified in the scenarios can be found in Annex 2 .

\subsection{Summary of situational analysis}

The analysis in this section has highlighted various factors that must be considered by Zanzibar's education decision-makers as they contemplate pursuing a VLE. The primary factors to consider are:

1. Most children are enrolling in school: In Zanzibar, the gross enrollment rates for both pre-primary (86 per cent) and primary (120.7 per cent) indicate that most children are entering school. Additionally, the student-teacher ratio is in line with international standards (i.e., circa $20: 1$ ), and is superior to that of other nearby countries such as Rwanda $(59: 1)$ or Mozambique $(55: 1)$. The fact that most children can access a school and a teacher is promising (Global Economy, 2018).

While these figures are positive, they mask challenges related to the number of hours children spend in school. In Zanzibar, many schools run multiple shifts in one day. These modalities have an impact on students' learning contact time and consequently on their performance. It is within this context that a VLE is necessary so that students can continue to learn in various environments even when a teacher is not present. However, challenges to deploying a VLE may arise from overcrowded classrooms and a lack of connectivity that allows students to access content.

2. Learning outcomes are low, are not improving and negatively impact student retention: Although most children enter the education system, assessment results indicate that learning is not occurring at expected levels. There are many factors that contribute to Zanzibar's low learning outcomes. These include unqualified teachers, insufficient mastery of English as the 
language of instruction and insufficient teaching and learning materials. Implementing a VLE may support Zanzibar in improving education quality through pathways such as providing digital textbooks, supplying engaging resources for teachers to use in classrooms, hosting relevant teaching and learning materials from websites, and giving students and teachers an opportunity to improve their digital literacy.

3. The policy environment supports the implementation of a VLE: Zanzibar's education policies are extremely progressive. While they do not explicitly advise the roll-out of a VLE into primary and secondary education, they generally support the integration of ICT into the teaching and learning process.

\section{Selecting and implementing a VLE will need consideration of the ICT} limitations imposed by the Zanzibar context: While some schools in Zanzibar have received computers and televisions, the approach to allocation means there are many computers in some schools, and no computers in many schools. Additionally, while most schools have electricity, many are not yet connected to the internet. The selection of a VLE will need to consider how this content can be best accessed in classrooms given these limitations.

5. Teachers' and administrators' ICT capacity must be built to ensure an appropriate return on investment: Currently, most teachers and many administrators do not have foundational levels of ICT literacy. If a VLE is implemented then a detailed plan should be developed which ensures that teachers, administrators and other stakeholders are adequately trained to integrate a VLE into their daily role. 


\section{Types of Virtual Learning Environments}

To understand how to proceed with pursuing a VLE it is important to outline the range of VLEs, content organisation and implementation models. This section presents a summary of global VLE options and how these options may apply in Zanzibar.

A VLE consists of two main parts: the learning content and an interface, sometimes called a Learning Management System (LMS). The content and the Learning Management System work together but can be developed separately and to some extent independently. A content base is the content that will be used in teaching / learning processes. In this case, all content is electronic, and may include files of print materials, video, audio files, etc. This content can be shared through an LMS, but can also be made available through a simple website or through a dongle that only contains content. An LMS is the platform through which content can be delivered. It can be agnostic to the content used.

There is often no clear distinction between the terms VLE and LMS. For example, when we have a playlist of videos in YouTube that covers the curriculum, it is not considered a VLE; if there is a dedicated website that provides access to the same content, it is usually called a VLE. In this report, when we use the term Virtual Learning Environment, we refer to the integration of a content base with a Learning Management System.

Since content and the VLE can be viewed separately, below we will first discuss content, ways to organise content and content curation. Different types of interfaces, or LMSs, are then discussed. Finally, we explore how they can fit together in the Zanzibar context.

\subsection{Types of content organisation}

Content can be provided in different ways. The least complex is a content repository: a collection of content which users navigate for relevant content. A scaffolded content repository is more complex. Here, content is aligned to learning goals and usually offered in a structured way. Khan Academy is an example of a scaffolded content repository. Finally, you can also have a scaffolded, curriculum-aligned repository. This means that content is provided according to a specific curriculum, taking into account expected learning levels and learning points and the language(s) of the learners. Table 12 provides an overview of different approaches to content organisation.

Table 12. Content organisation in an LMS (McBurnie, 2020).

\begin{tabular}{|l|l|}
\hline Content organisation & Definition \\
\hline Content repository & $\begin{array}{l}\text { A collection of content. Users typically can filter by } \\
\text { subject, language, content type, etc. }\end{array}$ \\
\hline Scaffolded content repository & $\begin{array}{l}\text { A collection of content that is organised around } \\
\text { learning goals and offered in a structured way. }\end{array}$ \\
\hline $\begin{array}{l}\text { Scaffolded, curriculum-aligned } \\
\text { repository }\end{array}$ & $\begin{array}{l}\text { A collection of content that is structured and offered } \\
\text { according to a specific curriculum. }\end{array}$ \\
\hline
\end{tabular}


Each design has advantages and disadvantages, but in general the complexity increases with its usefulness.

A content repository is fastest to curate, since there are many Open Educational Resources (OER) that can be used. A downside is that in practice, teachers and students find it challenging to find relevant content for their needs. Even when they find content for teaching or learning a certain skill, the content may be inappropriate: a skill may be explained differently from the way it is in the textbook, the content may contain too much or too little information, may be too difficult or too simple, or in a language that learners do not understand.

A scaffolded content repository allows teachers and students to find content more easily. However, if the content does not match the curriculum, information on necessary skills may be missing, and instead content on redundant skills may be offered. Besides, there is still a risk of the content being inappropriate with respect to local customs and culture.

Finally, a scaffolded, curriculum-aligned content repository provides content in line with the curriculum. Students and teachers can easily find content that is relevant, and can rely on the content being appropriate: in the right language, of the right level, containing the right amount of information, etc. The challenge with creating a scaffolded, curriculum-aligned repository is that it requires careful selection of content and often adjustment of content.

Advantages and disadvantages of the different ways of organising content can be found in Table 13.

Table 13. Advantages, disadvantages and costs of different content organisation models.

\begin{tabular}{|l|l|l|l|}
\hline Content organisation & Advantage & Disadvantage & Cost \\
\hline Content repository & $\begin{array}{l}\text { Easiest and fast to build } \\
\text { or curate }\end{array}$ & $\begin{array}{l}\text { Difficult to navigate for } \\
\text { students and teachers } \\
\text { alike; content not always } \\
\text { relevant for curriculum }\end{array}$ & $\$$ \\
\hline $\begin{array}{l}\text { Scaffolded content } \\
\text { repository }\end{array}$ & $\begin{array}{l}\text { Students and teachers } \\
\text { know which content to } \\
\text { use }\end{array}$ & $\begin{array}{l}\text { Content is not always } \\
\text { relevant for curriculum } \\
\text { and can even contradict } \\
\text { the curriculum }\end{array}$ & $\$ \$$ \\
\hline $\begin{array}{l}\text { Scaffolded, } \\
\text { curriculum-aligned } \\
\text { repository }\end{array}$ & $\begin{array}{l}\text { Students and teachers } \\
\text { know which content to } \\
\text { use, and content is } \\
\text { always appropriate }\end{array}$ & $\begin{array}{l}\text { Requires localisation, } \\
\text { adjustment of some } \\
\text { content and translation, if } \\
\text { content is curated }\end{array}$ & $\$ \$ \$$ \\
\hline
\end{tabular}

The ideal situation is to have access to a scaffolded, curriculum-aligned repository. In this situation, students and teachers can rely on all content being relevant and 
appropriate for the local curriculum, and have it available in the language(s) in which the curriculum is taught.

Most content can be distributed through any LMS. However, in some cases, content needs to be adjusted for a specific LMS or will not work on every platform. Content in Flash format, for example, is becoming obsolete and will not run on every LMS. Also, some types of content, such as video content, require considerable space on devices or will result in high data traffic if used online.

\subsection{Types of Learning Management System}

An LMS is the interface that users engage with to access content. For example, through a website or an app. It allows the content to be presented in attractive ways, and it may provide access to quizzes, discussion boards, include embedded links, or have other features. Some LMSs offer different learning paths or different content to students, based on their learning results, or their profiles. We generally group types of LMS according to their dimensions. In the case of Zanzibar, it is important to differentiate between modes of interaction and how this might subsequently impact connectivity requirements. The terms Learning Platform and Learning Management System (LMS) are often used interchangeably.

Communication through LMSs can be synchronous or asynchronous. A synchronous LMS lets people interact directly and in real time, for example through chat or meeting software. These LMSs need to be online and require a reliable and fast internet connection. An asynchronous LMS allows for communication that is not direct or real-time. Discussion boards or email functionality are examples of asynchronous communication. Some LMSs that work offline can connect to or synchronise with the internet regularly. These LMSs sometimes also allow asynchronous communication.

Online LMSs have advantages and disadvantages compared to offline ones. An online LMS requires an internet connection. It is cheaper and faster to implement and update and content can be streamed from the internet. However, an online LMS is not feasible if there is no internet connection, the connection is too weak or the data package is limited.

Many offline LMSs are actually hybrid: they can use an internet connection, when there is one, to update content, synchronise user data or retrieve asynchronous communication. These are also fully functional when there is no internet connection. However, offline platforms require more effort to install and update and also make it more challenging to retrieve learning data. Table 14 gives an overview of these learning platforms and provides examples. 
Table 14. Types of Learning Management System (McBurnie, 2020) .

\begin{tabular}{|c|c|c|}
\hline Learning Platform & Definition & Examples \\
\hline $\begin{array}{l}\text { Communication: } \\
\text { synchronous }\end{array}$ & $\begin{array}{l}\text { A platform that allows for real-time } \\
\text { communication between users (e.g,. } \\
\text { chat or video). Generally also allows } \\
\text { asynchronous communication. } \\
\text { Requires a continuous and reliable high } \\
\text { bandwidth internet connection. }\end{array}$ & $\begin{array}{l}\text { 1. } \frac{\text { Google }}{\text { Classroom }} \\
\text { 2. } \frac{\text { Edmodo }}{\text { Edmo }} \\
\text { 3. Jaggo }\end{array}$ \\
\hline $\begin{array}{l}\text { Communication: } \\
\text { asynchronous }\end{array}$ & $\begin{array}{l}\text { A platform that allows for } \\
\text { communication that is not immediate } \\
\text { (e.g., email or chat boards). Does not } \\
\text { require continuous internet connection } \\
\text { but requires frequent connection. }\end{array}$ & 1. Moodle \\
\hline Connectivity: online & $\begin{array}{l}\text { An online platform that requires a } \\
\text { continuous connection to the internet. } \\
\text { For example, interactive activities } \\
\text { should be run from the internet. }\end{array}$ & 1. Moodle \\
\hline Connectivity: offline & $\begin{array}{l}\text { A platform that can be used on a } \\
\text { computer or other device without an } \\
\text { internet connection. Offline platforms } \\
\text { can be connected to download new } \\
\text { content or synchronise learner data. }\end{array}$ & $\begin{array}{l}\text { 1. } \frac{\text { Kolibri }}{\text { 2. Rachel Plus }} \\
\text { 3. } \frac{\text { Open }}{\text { Learning }} \\
\text { Exchange }\end{array}$ \\
\hline
\end{tabular}

\subsection{Virtual Learning Environments: implementation approaches}

A Virtual Learning Environment (VLE) can be used in different ways, from simple, teacher-led implementations, to more complex, personalised implementations. We discuss four implementation modes below.

1. Teacher-led implementations are the most straightforward. The teacher manages the selection of relevant content from the VLE and the delivery of the content in the classroom, and students see content, quizzes, simulations or other information on a projected screen or television. A teacher-led VLE implementation helps provide accurate, on-topic, curriculum-aligned content. This format is closest to traditional teaching, with a teacher in front of the classroom and in control of the pace of teaching / learning. It represents the lowest cost of these four implementations. A disadvantage is that any differentiation for different students must be teacher-led.

2. Group-based implementations allow students to access the learning material on shared devices. The teacher assists and guides students and the teacher's role changes in this implementation. The teacher introduces a subject, but their role is reactive and facilitating. An advantage of such an approach is that groups can be distributed according to needs. For example, one group of students works on remedial content and another group of students works on this week's material. For teachers, this is a bigger change from teacher-led implementation 
and requires a considerable shift in teaching techniques. It also represents a higher cost, with multiple devices needed for a classroom.

3. Individual implementations allow students to access material at their own pace and their own level. They require students to have their own logins and make it possible to track students. An advantage is that each student can progress at their own pace and do quizzes and tasks independently. Disadvantages are that students require their own devices and this implementation needs a VLE that allows tracking, and connectivity - albeit not continuously - to synchronise learner data.

4. Personalised implementations require a VLE that offers students content when they are ready for it. The student does not need to identify the content as the system automatically offers relevant content. For example, if a student fails a test for a skill, this kind of VLE may offer the student the opportunity to test or practise that skill again, or provide different content for that skill, or even a foundational skill prior to that skill. This implementation requires a sophisticated VLE and teachers who are comfortable with differentiated learning.

Table 15 provides an overview of different implementations of VLES.

Table 15. Implementations of Virtual Learning Environments.

\begin{tabular}{|c|c|c|}
\hline Implementation & Definition & Pros and cons \\
\hline Teacher-led & $\begin{array}{l}\text { All students access } \\
\text { learning material on a } \\
\text { single screen or TV } \\
\text { controlled by the teacher. }\end{array}$ & $\begin{array}{l}\text { - Straightforward: teacher remains } \\
\text { in control } \\
\text { - Lowest cost } \\
\text { - No differentiation between } \\
\text { students }\end{array}$ \\
\hline Group-based & $\begin{array}{l}\text { Students access learning } \\
\text { material on shared } \\
\text { devices. }\end{array}$ & $\begin{array}{l}\text { - Groups of students can work at } \\
\text { their own pace } \\
\text { - High investment in devices } \\
\text { - Change in teaching techniques }\end{array}$ \\
\hline Individual & $\begin{array}{l}\text { Students can access } \\
\text { learning material in school } \\
\text { or at home, on their own } \\
\text { device. }\end{array}$ & $\begin{array}{l}\text { - Students work at their own pace } \\
\text { - Requires more advanced VLE } \\
\text { - Requires individual devices } \\
\text { - Change in teaching techniques } \\
\text { - High investment in devices } \\
\text { - Change in teaching techniques } \\
\text { - Requires adequate electricity and } \\
\text { internet connectivity }\end{array}$ \\
\hline Personalised & $\begin{array}{l}\text { Students access their } \\
\text { learning material, and are } \\
\text { offered material or test } \\
\text { questions that are } \\
\text { relevant for their } \\
\text { individual level. }\end{array}$ & $\begin{array}{l}\text { - Offers students appropriate and } \\
\text { timely content, e.g., remedial or } \\
\text { foundational } \\
\text { - Requires sophisticated VLE } \\
\text { - Requires individual devices } \\
\text { - Requires advanced teaching } \\
\text { techniques }\end{array}$ \\
\hline
\end{tabular}




\begin{tabular}{|l|l|l|}
\hline & $\begin{array}{l}\text { - High investment in devices } \\
\bullet\end{array}$ \\
& Change in teaching \\
& techniques \\
& $\begin{array}{l}\text { Requires adequate electricity } \\
\text { and internet connectivity }\end{array}$ \\
\hline
\end{tabular}

The content, VLE and implementation approaches discussed in this section have ramifications for hardware and connectivity needs for a full deployment model. Their integration and interdependence are explained in Section 6.2.1, where we present VLE options for Zanzibar. 


\section{Recommendations}

The previous sections outlined the Zanzibar context and analysed the different types of VLEs and content deployment approaches. Based on that discussion, this section provides recommendations to the MoEVT on how to address the challenge of providing access to good-quality content to all students in the region, in school or at home. The section begins with a set of general recommendations focused on how to best address this challenge. It then makes recommendations for the short and medium to long term.

\section{Box 1. From recommendations to next steps.}

The recommendations lead logically to various next steps that the MoEVT can take to move forward with implementing a content repository in the short term and a Virtual Learning Environment in the medium to long term. In addition to these recommendations the next section contains concrete actions that can be pursued in both the short and long term.

\subsection{Recommendation 1: Focus on quickly building and publishing a content base}

Content selection, curation, adaptation and development can begin immediately. Ideally, this content should be sourced from existing content repositories that are suitable for the region, low in cost, and require the least modification. This content base should be well structured and organised to fit different distribution models, including existing channels. One logical website for quick distribution online could be a website like zlms.moez.go.tz, which was designed and is managed by the MoEVT, Zanzibar. In parallel, the first steps recommended for trialling a VLE can be taken.

\subsection{Recommendation 2: Clearly define roles and responsibilities}

Effective implementation of a VLE requires clearly defined and distinct roles and responsibilities. This applies not only within the Ministry, but also to expected donor roles and all the different types of user. These different individuals, agencies, partners and implementers need tight coordination as well as an understanding of their role. Tables 9,10 and 11 highlight more than 15 agencies and user groups who will need to be involved in the deployment and implementation of a VLE in Zanzibar. A lack of clear role articulation and collaboration may lead to parallel actors fulfilling the same tasks and create inefficiencies and confusion.

Identifying roles and assigning ownership and responsibilities is a prerequisite to making implementation a success. While the initial work undertaken to inform this report included some initial scoping of roles and behaviours, a full mapping of all stakeholders, including their current roles and responsibilities, should be performed to ensure that all potential roles and responsibilities are identified and documented. These should then be clearly communicated to relevant parties to ensure that they are aware 
of the roles they are expected to play. This process can begin in parallel with the creation of a robust content base.

\subsection{Recommendation 3: Build capacity to execute roles}

Once all roles and responsibilities have been identified, actors should be supported to build the capacity they require to execute those roles. Targeted support is needed for roles such as content curation and design, teacher training to integrate digital content into teaching, infrastructural procurement and roll-out, system administration or ICT support.

In some cases, capacity to execute a role will already be in place. In other cases, the capacity may be available in Zanzibar but not in schools or the MoEVT. In this case, new staff may need to be employed and / or capacity development activities undertaken. Finally, in yet other cases, capacity may not be available in Zanzibar. In these cases, international consultants or firms may need to be engaged to provide initial services and capacity development.

\subsection{Recommendation 4: Create an iterative process of piloting and trialling VLES}

This recommendation is not about a specific implementation model, but rather an approach and process for implementing any model. Zanzibar's context is unique. It is important that any VLE is adequately tested and adapted to ensure both effectiveness and sustainability. The MoEVT should pursue an iterative process of piloting and rolling out a VLE to ensure that any solution aligns with the local context. This process should trial a number of different platforms, as well as corresponding teacher professional development approaches, adapting approaches that show promise and dismissing those that do not. After multiple small-scale trials, the most effective and sustainable approach should be scaled up. A full cost-of-ownership assessment and an evaluation of the return on investment is a prerequisite to scaling up. Rigorous monitoring and evaluation of a VLE's effect on learning outcomes should be undertaken, with the expectation of continuous change over time, based on what the monitoring and evaluation shows. 


\section{Next steps}

The above recommendations form a logical foundation for concrete next steps that the MoEVT can take towards implementing in the short term: a content repository; and in the medium to long term: a Virtual Learning Environment. We have broken down the section into short-term and long-term steps.

\subsection{Next steps in the short term}

Short-term interventions are those implemented in direct response to the COVID-19 crisis. These have a horizon from one month to a year from the start of the process. The steps meet four criteria:

1. they can be implemented relatively fast;

2. any investment should align with long-term aims;

3. they help maintain or improve learner outcomes;

4. any content should align with the national curriculum.

In line with our first recommendation, short-term steps should focus on ensuring content is made available to students to support learning continuity during the COVID-19 crisis. This requires acquiring a robust content base and identifying mechanisms to reach all students, including the most marginalised.

\subsubsection{Content selection, curation and adaptation}

The purpose of content curation is to create a content base that can be used immediately. The content base should be flexible enough to be used through different modalities (SMS, TV, internet, MoEVT Website). It should also be sufficiently robust to be a foundation for a content base for Zanzibar for the next 15 years. So while it can start immediately, this process applies to the long term as well. A content curation approach might include the steps in figure 6. 




Consistent with the trialling and piloting process advocated in our fourth recommendation, such a content curation approach can be started, tested and refined for a small subset of the curriculum first, for example Form 2 Biology. Once the process has been mastered and adapted to be effective in Zanzibar's environment, the approach can be scaled to larger segments of the curriculum. While the content curation and adaptation approach will be explored further in the second EdTech Hub deliverable, a brief explanation of each of these steps is included below.

1. Creating a skills taxonomy based on the curriculum: A skills taxonomy breaks down the curriculum by skills in all subjects for all grades. It identifies skills by name, but also contains the learning points for each skill. This allows curators to select existing content and identify if change is required. While this is an extensive framework to develop, it can be built quickly by the region's curriculum developers.

2. Identifying existing content sources: There are several content repositories that allow for content to be reused non-commercially. Good quality repositories that allow re-use and modification of free resources are the most important sources of content. Some free content repositories do not allow modification of content, such as the CC-ND license. An example of an extensive content base is Khan Academy. Khan Academy offers considerable content for a range of skills to practice in maths and science, and allows them to be used and modified. It also has a wide range of content for skills practice in Swahili. For primary content in Zanzibar, Ubongo offers Swahili content. More examples of Swahili content bases can be found in Annex 1.

3. Mapping content to the skills taxonomy: Content should then be mapped to the skills taxonomy, and categorised according to applicability. For example, video content can be used online and be broadcast through television, but is not suitable for feature phones or radio. There may be no, one or several content items available for a 
particular skill. This mapping can also contain information on the duration of an audio or video file or on file size.

4a. Adapting content for substance: Content may require technical adjustments. Text content available for the internet can be in a file format like HTML5; the same content for SMS needs to be presented differently. This requires standards for the different dissemination modalities that are in use. Videos, for example, may need to be rendered in a low-resolution format.

4b. Adapting content for format: Content may also require changes in substance. Existing content may need to be adjusted to fit the curriculum. That may mean changing, cutting or adding to the content, or it may require a voice-over in Swahili. This kind of adaptation is a task for education specialists, and along with the creation of new content, is the most labour-intensive step in this curation process.

4c. Creating essential missing content: After the curation process, there will be gaps in content that cannot be filled by curation. In the short term, it is best to accept gaps in the content base. However, if a skill is deemed absolutely essential, content can be created from scratch. In the medium to longer term it is important to create content to ensure there are resources to address all elements of the curriculum.

5. Testing your content: For content to be appropriate - in the correct language, with terminology that is understood, with the correct pace and matching the practice of teaching - content needs to be user-tested with students and teachers, especially at the beginning of the curation process. This process should include deaf students and students who are visually impaired. This user-testing will further inform the content standards.

6. Offering your content: scaffolded and curriculum-aligned: A content base is most useful to teachers and students if the content is aligned with the curriculum. The skills taxonomy and content mapping will make this part easy and ready for any future implementation.

A content base can be generated quickly with gaps filled over time, or curated content can be replaced by custom-made content. This process can start quickly. A first, incomplete, content base can be created in two months. Table 16 contains a rough timeline. It should be noted that content curation, creation and maintenance is an ongoing process. So while a first content base can be available in two months, a complete content base, that covers the curriculum, takes longer to develop and depends on the availability of existing content that can be curated.

Table 16. Timelines for curating and creating content for students.

\begin{tabular}{|l|l|}
\hline Step & Period \\
\hline $\begin{array}{l}\text { 1. Analyse curriculum and build skills } \\
\text { taxonomy }\end{array}$ & 1 month from start \\
\hline 2. Identify usable content bases & 1 month from start \\
\hline 3. Select usable content items for & 1 month after step 1 and ongoing \\
\hline
\end{tabular}




\begin{tabular}{|l|l|}
\hline \multicolumn{1}{|c|}{ identified skills } & \\
\hline 4. Adapt content for substance & First content ready, 1 month after step 3 \\
\hline 5. Adapt content for format & First content ready, 1 month after step 3 \\
\hline 6. Create missing content & First content ready, 2 months after step 3 \\
\hline 7. Test content with students & Immediately after step 3 \\
\hline 8. Offer content through website & Immediately after step 3 \\
\hline
\end{tabular}

\subsubsection{Content delivery}

A delivery mechanism is needed to get content to teachers and students. Short-term delivery is most effective through existing tools: televisions, radios, feature phones and smartphones. Once the content exists it can be delivered through different channels: a quiz can work on an SMS system or can be displayed on a screen in a classroom, although the content will need technical adjustments. Immediate delivery can take place via radio and television and the government website.

Table 17 offers an overview of the different delivery models that can work in Zanzibar. In all cases, capacity development for teachers is necessary.

Table 17. Short-term implementations of content in Zanzibar.

\begin{tabular}{|l|l|l|}
\hline Modality & Pros & Cons \\
\hline $\begin{array}{l}\text { Through the 23 hubs } \\
\text { A local server allows } \\
\text { students to connect to } \\
\text { content through a phone or } \\
\text { tablet }\end{array}$ & $\begin{array}{l}\text { Local server does not } \\
\text { need connectivity and } \\
\text { can be side-loaded }\end{array}$ & $\begin{array}{l}\text { - Local server needed } \\
\text { Devices very costly to } \\
\text { procure and maintain } \\
\text { (e.g., Rachel device is } \\
\$ 500)\end{array}$ \\
\hline $\begin{array}{l}\text { In school } \\
\text { Television or radio and } \\
\text { broadcast materials }\end{array}$ & $\begin{array}{l}\text { Requires tested } \\
\text { technology (TV or radio) } \\
\text { Government has } \\
\text { experience of } \\
\text { broadcasting content as } \\
\text { part of its COVID-19 } \\
\text { response }\end{array}$ & $\begin{array}{l}\text { Broadcasting does not } \\
\text { offer flexibility in timing }\end{array}$ \\
\hline $\begin{array}{l}\text { In school } \\
\text { Teachers display content in } \\
\text { the classroom via a TV } \\
\text { screen \& media player }\end{array}$ & $\begin{array}{l}\text { Requires tested } \\
\text { technology (TV or radio) } \\
\text { Media players (e.g., } \\
\text { dongle, DVD-player) are } \\
\text { robust and affordable } \\
\text { DVDs or dongles can be } \\
\text { delivered or new } \\
\text { content downloaded }\end{array}$ & $\begin{array}{l}\text { Also requires a media } \\
\text { player }\end{array}$ \\
\hline
\end{tabular}




\begin{tabular}{|c|c|c|}
\hline $\begin{array}{l}\text { In school } \\
\text { Teachers display content in } \\
\text { the classroom via a } \\
T V \text { screen / projector \& } \\
\text { online content repository }\end{array}$ & 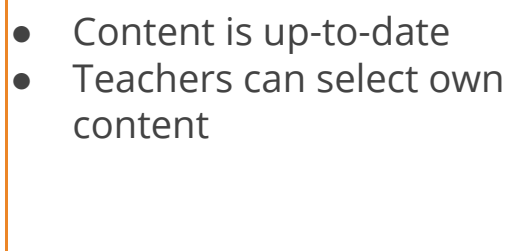 & $\begin{array}{l}\text { - Requires device } \\
\text { (computer) to stream } \\
\text { - Requires reliable, fast } \\
\text { internet } \\
\text { - Costly }\end{array}$ \\
\hline $\begin{array}{l}\text { At home } \\
\text { Feature phone and content }\end{array}$ & $\begin{array}{l}\text { - SMS and IVR can be } \\
\text { offered at no cost to } \\
\text { learners } \\
\text { - Many households have } \\
\text { a telephone }\end{array}$ & 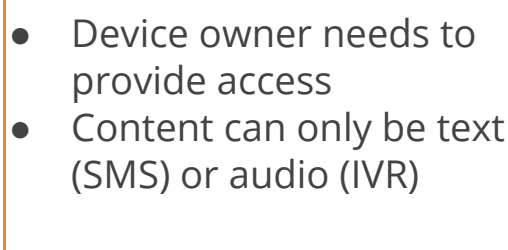 \\
\hline $\begin{array}{l}\text { At home } \\
\text { Smartphone for teacher } \\
\text { interaction }\end{array}$ & $\begin{array}{l}\text { - Good way for teachers } \\
\text { to interact and provide } \\
\text { feedback } \\
\text { - Zanzibar has experience } \\
\text { - Zero-rating is an option }\end{array}$ & $\begin{array}{l}\text { - } \text { Requires internet } \\
\text { - } \text { Requires smartphone; } \\
\text { - } \text { Device owner needs to } \\
\text { provide access } \\
\text { - Parents' buy-in } \\
\text { necessary }\end{array}$ \\
\hline $\begin{array}{l}\text { At home } \\
\text { Smartphone / tablet and } \\
\text { content }\end{array}$ & $\begin{array}{l}\text { - Zanzibar has some } \\
\text { experience with this } \\
\text { - Students can access } \\
\text { appropriate content } \\
\text { - Zero-rating is an option }\end{array}$ &  \\
\hline $\begin{array}{l}\text { At home } \\
\text { Radio and television } \\
\text { broadcast }\end{array}$ & $\begin{array}{ll}\text { - } & \text { Requires tested } \\
& \text { technology (TV or radio) } \\
\text { - } & \text { Zanzibar has experience }\end{array}$ & $\begin{array}{l}\text { - Not all households have } \\
\text { access to television } \\
\text { - Not flexible: content } \\
\text { broadcast at } \\
\text { predetermined slots }\end{array}$ \\
\hline
\end{tabular}

Thanks to its quick response to COVID-19, Zanzibar can now build on initiatives it had started immediately after the beginning of the pandemic. These include expanding or maintaining content dissemination through smartphones, radio and TV broadcasts. A second, quick step is the use of comparatively affordable and easy technology in classrooms, such as radio or TV screens connected to local media players. Whichever combination of delivery models is used, a monitoring and tracking mechanism is essential to track usage, implementation fidelity and learning outcomes.

\subsection{Next steps in the medium to long term}

By long term we mean roughly one to ten years. This length of time allows for planning, policy adjustments, procurement and training etc. to take place. The short-term approaches outlined above will lay the foundation for the longer term. 


\subsubsection{Virtual Learning Environment: options for Zanzibar}

Section 3 outlined the state of Zanzibar's education system, paying particular attention to factors which may impact the deployment of a VLE. Zanzibar's schools have few computers or devices, not all have electricity and there is no information on connectivity. While some citizens have personal devices including phones and television, less than half of the population have a mobile phone, and the number of people with broadband internet or a computer is negligible.

Despite these challenges, there are still a number of solutions that could be effectively deployed in Zanzibar. Section 4 discussed types of content organisation, types of LMS, and approaches to implementing VLEs. Table 18 combines these organisations, types and approaches and identifies their requirements for connectivity and devices. The implementation and VLE models range from low-cost and least complex on the top left to higher-cost and more complex on the bottom right. A specific content organisation type is only mentioned when implementation requires it.

Table 18. Overview of internet needs and device needs with different VLES and implementations.

\begin{tabular}{|c|c|c|c|c|}
\hline & Offline & Online & $\begin{array}{l}\text { Asynchronous } \\
\text { (occasionally } \\
\text { online) }\end{array}$ & $\begin{array}{l}\text { Synchronous } \\
\text { (online) }\end{array}$ \\
\hline Teacher-led & $\begin{array}{l}\text { Internet: } \\
\text { can use occasional } \\
\text { internet or add } \\
\text { content via } \\
\text { dongles } \\
\text { Device: } \\
\text { Requires any } \\
\text { device with big } \\
\text { screen (projector, } \\
\text { LED) }\end{array}$ & $\begin{array}{l}\text { Internet: } \\
\text { Requires reliable, } \\
\text { high-speed } \\
\text { internet to stream } \\
\text { videos, activities, } \\
\text { tests. } \\
\text { Requires } \\
\text { computer } \\
\text { connected to big } \\
\text { screen (projector, } \\
\text { LED). }\end{array}$ & $\begin{array}{l}\text { Internet: requires } \\
\text { high-speed } \\
\text { internet, once or } \\
\text { several times per } \\
\text { day. } \\
\text { Devices: } \\
\text { Requires device } \\
\text { with big screen. } \\
\text { Asynchronicity } \\
\text { implies that } \\
\text { teacher } \\
\text { communicates } \\
\text { with students or } \\
\text { other teachers }\end{array}$ & $\begin{array}{l}\text { Internet: requires } \\
\text { reliable, } \\
\text { continuous, } \\
\text { high-speed } \\
\text { internet } \\
\text { Devices: } \\
\text { Requires } \\
\text { good-quality } \\
\text { laptop and big } \\
\text { screen per } \\
\text { classroom or } \\
\text { groups of classes; } \\
\text { cameras }\end{array}$ \\
\hline Group-based & $\begin{array}{l}\text { Internet: can use } \\
\text { occasional } \\
\text { internet or add } \\
\text { content via } \\
\text { dongles } \\
\text { Devices: } \\
\text { Requires multiple } \\
\text { devices per class }\end{array}$ & $\begin{array}{l}\text { Internet: requires } \\
\text { reliable, } \\
\text { continuous, } \\
\text { high-speed } \\
\text { internet } \\
\text { Devices: } \\
\text { Requires multiple } \\
\text { devices per class }\end{array}$ & $\begin{array}{l}\text { Internet: requires } \\
\text { high-speed } \\
\text { internet, once or } \\
\text { several times per } \\
\text { day. } \\
\text { Devices: } \\
\text { Requires multiple } \\
\text { devices per class }\end{array}$ & $\begin{array}{l}\text { Internet: requires } \\
\text { reliable, } \\
\text { continuous, } \\
\text { high-speed } \\
\text { internet } \\
\text { Devices: } \\
\text { Requires multiple } \\
\text { devices per class; } \\
\text { cameras }\end{array}$ \\
\hline Individual & $\begin{array}{l}\text { Internet: can use } \\
\text { occasional } \\
\text { internet, or add } \\
\text { content via } \\
\text { dongles } \\
\text { Devices: } \\
\text { Requires a device } \\
\text { per student; }\end{array}$ & $\begin{array}{l}\text { Internet: requires } \\
\text { reliable, } \\
\text { continuous, } \\
\text { high-speed } \\
\text { internet } \\
\text { Devices: } \\
\text { Requires a device } \\
\text { per student; }\end{array}$ & $\begin{array}{l}\text { Internet: requires } \\
\text { high-speed } \\
\text { internet, once or } \\
\text { several times per } \\
\text { day. } \\
\text { Devices: } \\
\text { Requires a device } \\
\text { per student; }\end{array}$ & $\begin{array}{l}\text { Internet: requires } \\
\text { reliable, } \\
\text { continuous, } \\
\text { high-speed } \\
\text { internet } \\
\text { Devices: } \\
\text { Requires a device } \\
\text { per student; }\end{array}$ \\
\hline
\end{tabular}




\begin{tabular}{|l|l|l|l|l|}
\hline & $\begin{array}{l}\text { advanced LMS; } \\
\text { No student } \\
\text { tracking possible }\end{array}$ & advanced LMS & advanced LMS & $\begin{array}{l}\text { cameras; } \\
\text { advanced LMS }\end{array}$ \\
\hline Personalised & $\begin{array}{l}\text { Internet: can use } \\
\text { occasional } \\
\text { internet, or add } \\
\text { content via } \\
\text { dongles } \\
\text { Requires a device } \\
\text { per student; } \\
\text { sophisticated LMS; } \\
\text { No student } \\
\text { tracking possible; } \\
\text { Content: requires } \\
\text { scaffolded, } \\
\text { curriculum-aligned } \\
\text { content }\end{array}$ & $\begin{array}{l}\text { Internet: requires } \\
\text { reliable, } \\
\text { continuous, } \\
\text { high-speed } \\
\text { internet } \\
\text { Requires a device } \\
\text { per student; } \\
\text { sophisticated LMS } \\
\text { Content: requires } \\
\text { scaffolded, } \\
\text { curriculum-aligned } \\
\text { content }\end{array}$ & $\begin{array}{l}\text { Internet: requires } \\
\text { high-speed } \\
\text { internet, once or } \\
\text { several times per } \\
\text { day. } \\
\text { Devices: } \\
\text { Requires a device } \\
\text { per student; } \\
\text { sophisticated LMS } \\
\text { Content: requires } \\
\text { scaffolded, } \\
\text { curriculum-aligned } \\
\text { content }\end{array}$ & $\begin{array}{l}\text { Internetiable, } \\
\text { celintinuous, } \\
\text { high-speed } \\
\text { internet } \\
\text { Devices: } \\
\text { Requires a device } \\
\text { per student; } \\
\text { cameras; } \\
\text { sophisticated LMS } \\
\text { Content: requires } \\
\text { scaffolded, } \\
\text { curriculum-aligned } \\
\text { content }\end{array}$ \\
\hline
\end{tabular}

This table can help inform how the MoEVT move toward implementing a VLE. An incremental approach will be most useful for Zanizbar. This would include: building a foundation with an approach that has the most modest requirements to be effective, and then building on this experience to expand towards a more sophisticated option. While the table presents implementation models of LMSs, it does not outline implementation beyond infrastructure. Any implementation requires recurring costs and continuous efforts on many levels, beyond infrastructure. For example, in schools alone, this would include:

- purchasing devices;

- a storage and charging system in schools for devices;

- a maintenance contract for devices;

- strategies to deal with device loss and or breakage;

- batteries to ensure reliable electricity;

- assigning ownership and allocating staff for device maintenance;

- recurring training for supporting staff;

- recurring training for teaching staff;

- ICT support.

Ideally, any implementation would make use of existing infrastructure. In Zanzibar's case, infrastructure is limited: with one student computer and television available per school on average, and no other devices and no connectivity, and further, not all schools have electricity. Students do not have access to devices at home, other than their parents' phones, radio and television. Changes that are incremental and that expand on existing practices are more likely to succeed than changes that are substantial, that need a revolution in work practices and that require new budgets.

\subsubsection{Implementation strategy}

We recommend an incremental approach with our final recommendation: an iterative process where a next step is taken if 1) prerequisites are in place; and 2) monitoring and evaluation suggests that the path taken is effective. This entails trialling and piloting and requires vigorous evaluation of these pilots. 
The advantages of this approach are that several implementations can happen in parallel and no large-scale investment is made for an implementation that is not effective. A disadvantage is that the process takes time. However, several pilots can and should run at the same time. Table 19 describes possible steps in testing implementations. Depending on the pilot, cycles can be smaller scale and shorter in duration, or larger scale and longer lasting.

Table 19. Process for testing and implementing VLEs in the long term.

\begin{tabular}{|c|c|}
\hline Step & Description of steps \\
\hline Select implementation & $\begin{array}{l}\text { Select specific VLE based on needs (offline, online, } \\
\text { in-class, at home, etc.) }\end{array}$ \\
\hline Create budget & $\begin{array}{l}\text { A budget will tell you whether scale-up of this } \\
\text { implementation is feasible for the entire region }\end{array}$ \\
\hline Check prerequisites & $\begin{array}{l}\text { Which hardware is needed (server, devices, router, } \\
\text { dongles); which capacity is needed; is connectivity } \\
\text { needed? }\end{array}$ \\
\hline Prepare implementation & $\begin{array}{l}\text { Adjust interface, upload content, design teacher } \\
\text { professional development and training activities }\end{array}$ \\
\hline Identify set of schools & $\begin{array}{l}\text { A representative sample is best if you want to know if } \\
\text { an implementation will work for an entire region }\end{array}$ \\
\hline Identify control group & $\begin{array}{l}\text { A representative sample without the implementation } \\
\text { allows you to compare changes in learning outcomes }\end{array}$ \\
\hline Implement for 6 months & Actual implementation \\
\hline Monitor, track and evaluate & $\begin{array}{l}\text { Vigorous usage tracking and monitoring of the } \\
\text { process is needed to establish if the implementation } \\
\text { is effective }\end{array}$ \\
\hline Create new budget & $\begin{array}{l}\text { Based on the evaluation, what is the budget for a } \\
\text { region-wide implementation? }\end{array}$ \\
\hline Assess return on investment & Does the impact justify the cost? \\
\hline $\begin{array}{l}\text { Scale up, adjust and repeat, } \\
\text { or drop }\end{array}$ & $\begin{array}{l}\text { Scale up, adjust implementation and repeat the } \\
\text { process, or reject the implementation }\end{array}$ \\
\hline
\end{tabular}

This iterative process can be thought of as a cycle. After an analysis, one or several models can be selected and implemented for one term, in one to five schools. Then solutions can be evaluated for promise and potential for scale, their implementation design can be adjusted based on this evaluation, and a larger implementation of ten to twenty schools can commence. Again, this evaluation will allow you to keep the VLEs 
that are suitable, and a one-year implementation in 100-200 schools can take place. Figure 7 describes this process.

Figure 7. Iterative process of trialling and scaling implementation models



\subsection{Summary of the recommendations and next steps}

Our recommendations are based on the actual situation in Zanzibar and on the needs of the government. As a result of the extensive discussions and the wealth of data that the MoEVT has shared, we feel confident that there is a pathway to implementing a VLE in Zanzibar. Our recommended approach separates the development of content from the development of the interface. The government in Zanzibar should start immediately building a comprehensive, curriculum-aligned content base, with curated content where possible. In the longer term, a process of trialling and piloting VLE interfaces will build capacity, inform the government on what works, and allow it to scale up. 


\section{References}

Department of Planning, Policy and Research. (2019). Education Statistical Abstract 2016-2018 (Unpublished). The Ministry of Education and Vocational Training.

Global Economy. (2018). Student teacher ratio, primary school in Africa. https://www.theglobaleconomy.com/rankings/student teacher ratio primary scho ol/Africa/

Mahzumi, A. (2020). Roles and responsibilities government (Unpublished).

McBurnie, C. (2020). Technical note on the use of virtual learning environments during the COVID-19 pandemic (EdTech Hub Helpdesk Request No. 7). https://docs.google.com/document/d/1MGAVhK OAJwUMr N6--d3AwvMCHZTFI M g6]2wCPC8I/edit?usp=sharing

Ministry of Education and Vocational Training. (2006). Zanzibar Education Policy. https://www.moez.go.tz/docs/pwA4nrszmk Zanzibar Education Policy.pdf

Ministry of Education and Vocational Training. (2017). Zanzibar Education Development Plan II 2017/2018-2021/2022.

https://www.globalpartnership.org/sites/default/files/zedp ii zanzibar.pdf

Ministry of Education and Vocational Training, Milele Zanzibar Foundation, \& UNICEF. (2018). Mapping of school capacity to absorb out-of-school children in Zanzibar: A review of school capacity. https://www.unicef.org/tanzania/media/1851/file

Ministry of Infrastructure and Communications. (2013). Zanzibar ICT Policy. Ministry of Infrastructure and Communications.

https://egoz.go.tz/index.php?option=com osdownloads\&task=routedownload\&tmp l=component\&id=5\&ltemid=101\&lang=en

Othman, O. S. (2019). Education District Profile, 2018 (Unpublished). Ministry of Education and Vocational Training.

Othman, O. S. (2020a). Disability, computer and school data in Zanzibar (Unpublished). EMIS Department MoEVT Zanzibar.

Othman, O. S. (2020b). School enrolment data (Unpublished). EMIS Department MoEVT Zanzibar.

RTI International. (2016). Assistance to Basic Education: All Children Reading (ABE-ACR) Findings Report, Tanzania National Early Grade Reading Assessment (EGRA). USAID. https://ierc-publicfiles.s3.amazonaws.com/public/resources/FdngsRpt TZNtnIEGRA 08-Nov2016 FNL.pdf

Tanzania Communications Regulatory Authority. (2020). Quarterly Communication Statistics January-March 2020. https://www.tcra.go.tz/statistic document/8/march 


\section{Annex 1 - Overview of existing platforms and content}

Zanzibar and Tanzania benefit from home-grown EdTech initiatives and from the advantage that the local language, Swahili, brings in solutions built for surrounding Swalihi speaking countries that can also be used there. The platforms below have been sourced through references, web searches, and the EdTech Hub's EdTech initiatives database. There are more initiatives in Tanzania than presented here - only initiatives that meet the following criteria have been considered:

1. The solution has a large user base in Zanzibar or Tanzania;

2. The solution has reached a certain level of maturity;

3. The solution specifically targets the Zanzibari curriculum in basic education;

4. The solution has content in Swahili.

For example, Eneza is included as it has content in Swahili and has reached around 8.5 million users, although it does not have a current presence in Zanzibar or in Tanzania. The initiatives are presented in Table 20.

Table 20. Existing platforms and content bases in Zanzibar and Tanzania.

\begin{tabular}{|l|l|}
\hline Platform & Details \\
\hline Zanzibar & $\begin{array}{l}\text { Overview: Video content on YouTube made by the MoEVT. } \\
\text { Technology: Videos available on YouTube } \\
\text { Reach / scale: } 418 \text { subscribers and less than 1,000 views per } \\
\text { video. Around 1,100 visitors per month, two thirds of which are } \\
\text { female. } \\
\text { Implementing partners: N/A } \\
\text { Government partners: Created by MoEVT. } \\
\text { Status of implementation: Started April 2020 }\end{array}$ \\
\hline HaloStudy & $\begin{array}{l}\text { Overview: Moodle-based curriculum-aligned content, created by } \\
\text { the Tanzanian College of Information and Communication } \\
\text { Technologies (ColCT) in partnership with Viettel Tanzania Ltd } \\
\text { (Halotel) } \\
\text { Target group: Secondary grades (Forms 1-4) in Tanzania } \\
\text { Technology: Moodle based LMS with scaffolded } \\
\text { curriculum-aligned content } \\
\text { Reach / scale: Unknown } \\
\text { Implementing partners: Viettel Tanzania Ltd (Halotel) } \\
\text { Government partners: Tanzanian College of Information and }\end{array}$ \\
\hline
\end{tabular}




\begin{tabular}{|c|c|}
\hline & $\begin{array}{l}\text { Communication Technologies (ColCT) } \\
\text { Status of implementation: Unknown }\end{array}$ \\
\hline$\underline{\text { Suza LMS }}$ & $\begin{array}{l}\text { Overview: State University of Zanzibar's Learning Platform } \\
\text { Target group: University students } \\
\text { Technology: Moodle-based, online LMS with academic content } \\
\text { Reach / scale: Unknown } \\
\text { Implementing partners: Unknown } \\
\text { Government partners: State University of Zanzibar } \\
\text { Status of implementation: Unknown }\end{array}$ \\
\hline DITNet & $\begin{array}{l}\text { Overview: Dar es Salaam's Institute of Technology's Learning } \\
\text { Platform } \\
\text { Target group: University students } \\
\text { Technology: Moodle-based, online LMS with academic content } \\
\text { Reach / scale: Unknown } \\
\text { Implementing partners: Unknown } \\
\text { Government partners: Dar es Salaam's Institute of Technology } \\
\text { Status of implementation: Unknown }\end{array}$ \\
\hline$\underline{\text { TTCIH }}$ & $\begin{array}{l}\text { Overview: Tanzanian Training Centre for International Health's } \\
\text { Learning Platform } \\
\text { Target group: Health workers in Tanzania } \\
\text { Technology: Joomla-based Content Management System } \\
\text { Reach / scale: Unknown } \\
\text { Implementing partners: Unknown } \\
\text { Government partners: Tanzanian Training Centre for } \\
\text { International Health } \\
\text { Status of implementation: Unknown }\end{array}$ \\
\hline Ubongo & $\begin{array}{l}\text { Overview: Ubongo creates educational television shows for } \\
\text { children from 3-12. } \\
\text { Target group: Primary and secondary } \\
\text { Technology: Most content is videos, available on TV and through } \\
\text { mobile apps. Ubongo also has an offering for feature phones. } \\
\text { Reach / scale: } 17 \text { million monthly in Africa, } 1.5 \text { million monthly } \\
\text { TV viewers in Tanzania, } 1.3 \text { million monthly radio listeners in } \\
\text { Tanzania, and } 3.8 \text { million YouTube visitors in Tanzania. } \\
\text { Implementing partners: HDIF, DFID, local television, Curious }\end{array}$ \\
\hline
\end{tabular}




\begin{tabular}{|c|c|}
\hline & $\begin{array}{l}\text { Learning, Enuma, Viamo } \\
\text { Government partners: N/A } \\
\text { Status of implementation: } 2013 \text { - present }\end{array}$ \\
\hline Shule Direct & $\begin{array}{l}\text { Overview: Tanzania-based NGO providing curriculum-aligned } \\
\text { content for Forms 1-4. } \\
\text { Target group: Secondary (Forms 1-4) in Zanzibar, Kenya, } \\
\text { Rwanda } \\
\text { Technology: Available online through a website; offline in } \\
\text { schools through a local server called Elimika LMS; a learning app; } \\
\text { an SMS-based solution called Makini SMS. } \\
\text { Reach / scale: } 2.2 \text { million through the website; 16,000 users } \\
\text { through the apps; } 34,000 \text { offline through Elimika LMS; 80,000 } \\
\text { through Makini SMS. } \\
\text { Implementing partners: National Microfinance Bank (NMB), } \\
\text { Camara Education, Read International, The Foundation for } \\
\text { Tomorrow; UNESCO; Tigo Tanzania's eSchools Project } \\
\text { Government partners: N/A } \\
\text { Status of implementation: } 2013 \text { - present }\end{array}$ \\
\hline E-Learning for Kids & $\begin{array}{l}\text { Overview: Non-profit organisation that provides around } 700 \\
\text { lessons for pre-primary and primary. With Flash content in the } \\
\text { process of being removed, at the end of } 2020 \text { around } 500 \\
\text { lessons will be left. } \\
\text { Target group: K to Standard Vl; global curriculum; content } \\
\text { repository, no scaffold. } \\
\text { Technology: Website and videos in HTML5; content } \\
\text { downloadable on request. } \\
\text { Reach / scale: No data on Zanzibar; in Tanzania, May } 2020 \text { had } \\
63 \text { unique online users. In Tanzania, there have been } 22 \\
\text { download requests benefiting } 7771 \text { children. } \\
\text { Implementing partners: N/A } \\
\text { Government partners: N/A } \\
\text { Status of implementation: Unknown }\end{array}$ \\
\hline OneBillion & $\begin{array}{l}\text { Overview: Building educational content for in-school and } \\
\text { out-of-school children in their own language. X-Prize winner in } \\
2019 . \\
\text { Target group: Pre-primary and primary; Swahili. } \\
\text { Technology: Integrated LMS and content on a tablet. } \\
\text { Reach / scale: } 500 \text { children in Tanzania until 2019; 150,000 }\end{array}$ \\
\hline
\end{tabular}




\begin{tabular}{|c|c|}
\hline & $\begin{array}{l}\text { globally. } \\
\text { Implementing partners: OneBillion, with RTI and Google } \\
\text { Government partners: N/A } \\
\text { Status of implementation: } 2014-2019\end{array}$ \\
\hline Elimu Tanzania & $\begin{array}{l}\text { Overview: Hadithi Hadithi app to improve literacy rates in the } \\
\text { first years of primary education. } \\
\text { Target group: Primary and secondary; English and Swahili } \\
\text { Technology: App } \\
\text { Reach/scale: } 80,000 \text { visitors } \\
\text { Implementing partners: N/A } \\
\text { Government partners: N/A } \\
\text { Status of implementation: } 2016 \text { - present }\end{array}$ \\
\hline $\begin{array}{l}\text { Global e-Schools and } \\
\text { Communities Initiative } \\
\text { (GESCI) / African Digital } \\
\text { Schools Initiative (ADSI) }\end{array}$ & $\begin{array}{l}\text { Overview: founded by the UN, GESCI uses ICT through its ADSI } \\
\text { programme to increase learning outcomes and improve the } \\
\text { transition to university. } \\
\text { Target group: Secondary school subjects } \\
\text { Technology: Hardware provision (projectors, laptops and } \\
\text { routers), } \\
\text { Reach / scale: } 31,000 \text { students, through } 40 \text { schools and } 500 \\
\text { teachers in Pwani and Morogoro. } \\
\text { Implementing partners: Mastercard Foundation } \\
\text { Government partners: MoEVT } \\
\text { Status of implementation: } 2016 \text { - } 2020\end{array}$ \\
\hline World Possible & $\begin{array}{l}\text { Overview: The provider is Rachel, a router that provides content } \\
\text { to connected devices, even when no internet is available. The } \\
\text { purpose is to provide Open Source content. } \\
\text { Target group: (Pre-)Primary up to vocational studies. } \\
\text { Technology: Linux router with offline capabilities and } \\
\text { pre-loaded with content from oer2go.org. } \\
\text { Reach / scale: } 200 \text { devices in } 15 \text { institutions. Location mapping } \\
\text { is available in Google Maps. } \\
\text { Implementing partners: UNICEF, Vodacom, Powering Potential, } \\
\text { Lyra, Tanzania Development Trust } \\
\text { Government partners: } \\
\text { Status of implementation: } 2018 \text { - present }\end{array}$ \\
\hline
\end{tabular}




\begin{tabular}{|c|c|}
\hline ProFuturo & $\begin{array}{l}\text { Overview: Teacher training, offline LMS with content and } \\
\text { provision of IT equipment in rural and remote areas. } \\
\text { Target group: Primary and lower secondary; English, no Swahili } \\
\text { Technology: Local offline LMS and tablets. } \\
\text { Reach / scale: } 102 \text { schools (in Dodoma, Mafinga - Iringa, } \\
\text { Songea, Moshi - Kilimanjaro, Dar es Salaam, Morogoro and } \\
\text { Zanzibar); } 2,000 \text { teachers and } 67,600 \text { children. } \\
\text { Implementing partners: Salesians of Don Bosco in Tanzania } \\
\text { Government partners: } \\
\text { Status of implementation: } 2016 \text { - present }\end{array}$ \\
\hline ekitabu & $\begin{array}{l}\text { Overview: Non-profit organisation creating content, including } \\
\text { content adjusted for learners with disabilities } \\
\text { Target group: Primary and secondary grades; children with } \\
\text { disabilities; curriculum-aligned; content in Swahili language } \\
\text { Technology: Device agnostic; available online and offline; } \\
\text { content available for a variety of LMSs } \\
\text { Reach / scale: no numbers provided } \\
\text { Implementing partners: Publishers; other partners } \\
\text { Government partners: } \\
\text { Status of implementation: } 2015 \text { - Ongoing }\end{array}$ \\
\hline Eneza Education & $\begin{array}{l}\text { Overview: Eneza offers a mobile-phone based learning platform } \\
\text { that allows users to access lesson programmes and ask teachers } \\
\text { clarifying questions through SMS } \\
\text { Target group: Students and teachers living in rural and } \\
\text { marginalised communities; Swahili } \\
\text { Technology: Basic mobile phones are used to deliver } \\
\text { supplementary learning and revision materials to students. } \\
\text { Reach / scale: no users. In 2017, a pilot started that did not } \\
\text { succeed. } \\
\text { Implementing partners: N/A } \\
\text { Government partners: N/A } \\
\text { Status of implementation: } 2017\end{array}$ \\
\hline $\begin{array}{l}\text { English Literacy E-Reader } \\
\text { Project }\end{array}$ & $\begin{array}{l}\text { Overview: Providing access to the curriculum through e-readers. } \\
\text { Target group: Secondary } \\
\text { Technology: Curriculum on E-Readers } \\
\text { Reach/scale: } 25 \text { schools and 4,500 girls } \\
\text { Implementing partners: Campaign for Female Education }\end{array}$ \\
\hline
\end{tabular}




\begin{tabular}{|c|c|}
\hline & $\begin{array}{l}\text { (CamFed), WorldReader, Kiva } \\
\text { Government partners: N/A } \\
\text { Status of implementation: } 2015-2017\end{array}$ \\
\hline WorldReader & $\begin{array}{l}\text { Overview: Open source reading books } \\
\text { Target group: Primary and secondary; English, Swahili and other } \\
\text { languages } \\
\text { Technology: Smartphone or e-reader } \\
\text { Reach / scale: 50,000 users in Tanzania; } 13.3 \text { million worldwide } \\
\text { since } 2010 . \\
\text { Implementing partners: UNHCR, Bill and Melinda Gates } \\
\text { Foundation, CamFed, local donors } \\
\text { Government partners: } \\
\text { Status of implementation: } 2012-2016\end{array}$ \\
\hline $\begin{array}{l}\text { Opportunity Education } \\
\text { Foundation (OEF) }\end{array}$ & $\begin{array}{l}\text { Overview: OEF creates content aligned with the Tanzanian } \\
\text { curriculum and rolls it out to schools. OEF provides content and } \\
\text { support, but hardware is the school's responsibility. They also } \\
\text { created a teacher peer support app (My Maarifa). } \\
\text { Target group: Forms 1-4 (Phase 1) and Forms 1-6 (Phase 2). } \\
\text { Both private and public schools. } \\
\text { Technology: Online content rolled out through cheap tablets } \\
\text { (such as Amazon's) that can limit access to other apps. Generic } \\
\text { Android app available mid-2020. } \\
\text { Reach / scale: } 30 \text { private schools in different parts of the } \\
\text { country. } \\
\text { Implementing partners: Private schools } \\
\text { Government partners: Tanzania Institute of Education (TIE) } \\
\text { Status of implementation: Phase } 12016-2021 \text {, ongoing; Phase } \\
2 \text { planned 2022-2027. }\end{array}$ \\
\hline
\end{tabular}




\section{Annex 2 - Usage scenarios}

A user scenario only works if we're meticulous in our story-telling, and include as many details as possible. The most effective way to go over this would be to tell a story about a typical student, which was started in the 11 June workshop and later expanded on.

Below are four scenarios:

1. 9-year old female student, going to primary school

2. 15-year old female student, going to secondary school

3. A primary school teacher

4. A secondary school teacher

The scenarios have been added unedited.

Five members of the MoEVT created imagined usage scenarios of students in a storytelling exercise. The purpose of these scenarios was to understand what relevant players in the Ministry envision in its implementation of a VLE; what teachers and students are expected to do; and how they're expected to use the VLE. Creating a story helps us identify both opportunities and risks in implementing a VLE in Zanzibar. By telling a story of a student or teaching using the VLE, we get an idea of

1. Do we agree on what we are looking for?

2. Do we all have the same understanding of a VLE?

3. What is needed to make a VLE work?

4. Do we have misconceptions about a VLE or possibilities?

A user scenario is most effective if we are meticulous in our story-telling, and include as many details as possible. The most effective way to go over this would be to tell a story about a typical student or teacher. To this end, four scenarios were delivered:

1. A 9-year old female student, going to primary school

2. A 15-year old female student, going to secondary school

3. A primary school teacher

4. A secondary school teacher

These scenarios are valuable and insightful since none of the four includes a successful usage scenario. In each of the four scenarios, usage fails and the reasons for failure are narrated. These scenarios allow us to identify and categorise the barriers to implementing a VLE in Zanzibar: there are problems in capacity; in the school situation; in computer infrastructure; in connectivity; and with content.

\subsection{Capacity}

- Teachers expected to work with the VLE have no experience in using computers, do not own devices, have not been trained and, for that reason, have no problem-solving skills on the computer or eagerness to use technology.

- As a result, teachers start using content online, requiring a data connection, instead of offline.

- Teachers are reluctant to use technology when they have no capacity. 
- Parents do not understand the curriculum their children are taught and do not know how to access content or make it available to their children.

\subsection{School situation}

- Teachers arrive late, leading to last-minute changes in the schedule of a lab or computer room.

- Classes are overcrowded (one scenario mentions 87 pupils), making it difficult to display a screen or manage with devices.

- Labs with hardware are typically even smaller than normal classrooms, so there is no capacity for a class in a lab.

- Classes are noisy and unsafe for students.

\subsection{Hardware problems}

- Schools have no devices, few computers, no screen, no supporting hardware

- When there is hardware, it is of low quality and badly maintained; for example, one of the scenarios mentions a broken cable from the computer to the projector - the cheapest part of the installation, but essential.

- Schools with electricity have power outages; unreliable electricity can stop the implementation.

- Teachers use their own devices instead of the schools.

\subsection{Bandwidth problems}

- Most scenarios mention the lack of connectivity. Even when a teacher or parent has a smartphone, the phone has no data, or cannot be charged with electricity.

- Teachers use their own smartphones in class to connect, since the school is not connected.

- Even when there is connectivity and data, the speed is too limited to be effective.

\subsection{Content problems}

- The content used in the scenarios is in English, and too difficult to understand.

- The content used in the scenarios is on a different level than the class's, and not aligned with the curriculum.

A challenge with a technical implementation like a VLE is that all conditions must be met before an implementation is successful. For example, even if classrooms are big enough, teachers are well trained, there are enough devices, there is continuous and reliable electricity, and there is a high capacity data connection, a VLE will not be successful unless the content aligns with the curriculum and is understood.

Based on the scenarios, Table 21 lists the necessary conditions that the scenarios identified for a successful VLE implementation in Zanzibar.

Table 21. Checklist of necessary conditions for a VLE according to the usage scenarios in Zanzibar

\begin{tabular}{|l|l|}
\hline Category & Necessary conditions \\
\hline Capacity & $\bullet$ Teachers have had training in teaching with technology \\
\hline
\end{tabular}




\begin{tabular}{|c|c|}
\hline & $\begin{array}{l}\text { - Teachers have had training in using and solving problems with } \\
\text { - Technology } \\
\text { - Teachers have access to a device at home or at work to increase } \\
\text { - Parents have been informed or trained on changes in the school }\end{array}$ \\
\hline School situation & $\begin{array}{l}\text { - Teachers are able to stick to the timetable in school } \\
\text { - Class size is reduced to a reasonable number } \\
\text { - Classes are quiet and safe }\end{array}$ \\
\hline Hardware & $\begin{array}{l}\text { - Schools have necessary devices } \\
\text { - Schools have a mechanism for maintaining and repairing } \\
\text { - Sardware } \\
\text { - Schools have good-quality and spare components } \\
\text { - Teachers are not required to use their own devices }\end{array}$ \\
\hline Bandwidth & $\begin{array}{l}\text { - Schools have reliable and continuous internet } \\
\text { - Internet is of sufficient speed } \\
\text { - The data package is sufficiently big }\end{array}$ \\
\hline Content & $\begin{array}{l}\text { - Content is available in Swahili, including for secondary school } \\
\text { - Content is aligned with the curriculum } \\
\text { - Content is on the right level for the students }\end{array}$ \\
\hline
\end{tabular}

\subsection{Nine-year old primary school student scenario: Mkinai}

MKINAI is a Std IV primary pupil, aged 9 years old. She gets up early in the morning, goes to school, and then goes back home at 1:10 pm.

When MKINAI is at school, she uses VLE in the computer lab. First, her teacher has introduced the topic during the science subject entitled soil and its types. MKINAI had to pay much attention since the commotions of fear, noisy pollution and large number of pupils in the huge class accompanied with limited lab equipments. Besides, the lab lacks large screen platform for easy and clarified information. Then the teacher gives her a home work related to the given topic.

MKINAI does not own a device on which she could do her homework; she then asks her mother if she could use her phone to do the homework. Since her mother has very close interaction among school and subject teachers, she reluctantly allows her daughter and hand the mobile smart phone. Worse enough, the phone however has no charge and there is no internet connectivity. She finds herself disappointed because she can 't complete her homework on time and at appropriate pace while other pupils will have completed their work accordingly.

In our scenario, MKINAI has seen the content and was supposed to do a quiz, unfortunately she could not complete her work simply because there is a failure in network connection. Since she could not submit homework, therefore her teacher could not track her work and MKINAI was disappointed. 


\subsection{Fifteen-year old secondary school student scenario: Asha}

Asha leaving with her parents and her young sister and brother. She spend about an hour walking to the schools every day. She is very interesting with science subjects among nine subjects she learns. Today the first period is Biology which should start at 0730 as but the teacher became 20 minutes late. Because he is leaving town canter and use public transport which is in some days is problematic. The students asked to shift the venue of learning form the class t the biology lab. It is classroom size improvised lab with very minimum space. Two concrete lay along the right and left walls, rough dressing rows of chairs which their number should be double to compare with the number of students. Therefore in today lesson every chair used by almost two students at a time.

The teacher planned to teach Blood Circulation, he intended to play a video from YouTube that show a simulation of human blood circulation. He uses his personal laptop that on the top of front teacher's bench and helped by huge biology books to make it quite higher to be seen by the students. After an introduction of the lesson the teacher asked the students to be very quiet and very focussed because there will be a home work that relating with the today's lesson. The video was played online because it seem the teacher has very limited skills to download it. The teacher uses his mobile hotspot to get a line with internet. The internet was quite poor strength in such a way the video was stacking frequently. Projection of the video was unrelated to the size of class in such a way a student like Asha set just two meters away could not see clearly the simulation. The teacher tries to pause the video in pace so as to make some clarification on the video and make some translations with simple language.

The class has finish after 40minites, the teacher could not make clear formative evaluation due to the video played during the lesson was not designed for the students like Asha. The language was very complicated with difficult terminologies in such a way even the teacher face difficulties on making translation in simple language. Not only the language but also the content was very advance and simulation was not relating to Asha's curriculum.

The next lesson in the day was English Language that was taught buy newly employed graduate teacher. The teacher planned to teach listing skills. The teacher was reading a story from her smart phone while the students asked to listing careful in such a way they will answer the questions that will follow. The teacher was reading a passage form whatsup page that she shared with her follow teacher from other schools. The passage seem to be very interesting to the students simple because it was bilingual read by the teacher. The students was laughing after repeating the sentences in Swahili language not at first time when it read by English language.

After the two sessions Asha got time to rest and chart with friends. She discuss with her follow students about the today's lessons particularly the home work given by the Biology teacher. Asha and her friends "Fatma" planned to find some help after school hours. They decide ask Fatma's brother to download the video played by the teacher earlier. At 1300 the school hour is finish Asha has to accompany Fatma's home to find the brother for the help. Fatma's home was not far from the school. After an hour the Fatma's brother finish to search the video and download it to his smart phone. Fatma 
and Asha try to play the simulation but still they need clarification in some ares but there is no one could do so at that time. Asha asked the Fatma's brother to forward the video to Asha's Father whatup Account so as to ask some help from him at home.

At evening Asha asked his father if he got the video sent by Fatma's Brother.

Surprisingly he glance to Asha's face and hesitatingly answer "Yes, but I delete at the spot after downloading it". He was very sorry and explain "I did understand the video and I did not think if that was yours". Asha could not say anything to her father because believe that is not his fault. Asha realises that his father even though knows English language well but know nothing about science subjects. Furthermore' she knows that if she got her own smart phone the mistake could not appear. And she know for sure even his father call Fatma's Brother to re send the video, it could not downloaded at home due to the network coverage is very poor for using mobile data. It doesn't matter the difficulties she faces the home work should be submitted early in the morning of the next day.

\subsection{Primary school teacher: Nyafu}

Teacher Nyafu is 53 years old. She is teaching at Vumbi primary school that located 3 kilometers from the village where she lives. Teacher Nyafu has enough experience to teach children from grades 1 to 6 , but she has no knowledge or understanding of the use of modern technologies such as computers, smart phones and projectors for teaching. She is accustomed to teaching using chalk and board and other teaching materials around her environment. She always says to their fellow teachers who motivate her to use modern style of teaching that "I didn't take any initiative in learning about using computers and mobile phones because I have not in my home, so it is difficult to understand how to use of such technological items.

One day at Vumbi primary school, he came a visitor who provided two computers and other small devices like flash discs and CDs with the aim of supporting primary school teachers so that these computers could help in the matter of simplifying how to teach children by observing and hearing different aspects of their subjects. But in the case of the teacher Nyafu, she never used a single tool. When she is encouraged by his/her fellow teachers about sharing the electronic materials she says aagh! You guys, if the rest of us have taught our students through it, how we can manage our devices due to such kind of over uses? How we can manage our time table and be free from collision of the period when all teachers using these computers? Also, do you know we have one student in standard IV who have difficulties (impair) in hearing and one student in standard I have the problem of short sighted?, how we can help them if we use such kind of devices? And more interesting, I myself I have no knowledge about using such things!

At that time teacher Nyafu seems is not ready to start teaching her students by using the new method (using computers) because of the obstacles she mentioned to her fellow teachers. However, the headmaster told his/her teachers that " it is better to use appropriately the one in his/her hands in a better manner rather than waiting for the good time that will able to manage to have the ample of equipments. After such advice, teacher Nyafu tried her best and started to set some days during the weekdays to learn how to use the computer that can help in her teaching process. 


\subsection{Secondary school teacher: Pandu}

Mr Pandu who is a graduate of the Mlimauni University is teaching at the Koja Secondary School. Teacher Pandu is a teacher who has worked hard to teach his students through the computer he has bought since he was a student. However, teacher Pandu has often faced the challenges of his computer being disrupted from time to time. But there are also some topics he likes to teach his students through YouTube that he has to buy MBs of data to enable him to download those videos for his students. The biggest challenge he faces is that he does not have enough Mbs for every subject he wants to teach on YouTube, so some days he finds himself disconnected with data in the middle of the lesson.

Further, the teacher Pandu class contained 87 students that also led to another challenge in teaching and in that way he finds it difficult to divide students into small groups as he teaches them through his computer. Thus, Pandu takes a lot of time to teach so that he can reach all students within the classroom. In some days, Teacher Pandu strives to teach his lesson in the computer room so that all students have the opportunity to sit and watch their lesson as it is projected on the wall, but during the class, teacher Pandu face the other biggest challenges of power outages, pupils cramping (room is small according to the number of students), the air is inadequate and leading to inadequate relaxation during teaching and learning. Similarly, through Projector which borrowed from a nearby school, teacher Pandu find the projector wire that is used to connect to the electricity is being unstable because is already damaged. 